\title{
Do characteristics of walkable environments support bicycling? Toward a definition of bicycle-supported development
}

\author{
Christopher D. Muhs \\ Portland State University \\ muhs@pdx.edu
}

\author{
Kelly J. Clifton \\ Portland State University \\ kclifton@pdx.edu
}

\begin{abstract}
Does walkability equate with bikeability? Through a comprehensive review of studies of the built environment and bicycling, including mode choice, route choice, safety, and urban design literature, this paper addresses this question. Previous work has raised the issue that the two modes are functionally different, despite them often being combined into a nonmotorized category, and has highlighted research challenges. Existing studies of bikeability have largely focused on infrastructure. This paper contributes to the literature on bicycling and the built environment by providing a thorough review of past research with a focus on the relationships between land use, urban form, and bicycling. Highly walkable and highly bikeable environments are quite different, and there is little consistency in the built-environment attributes associated with cycling across studies. We postulate that this inconsistency is due in part to a disconnect between theory and methods of measuring the environment for cycling along with data limitations, including sample sizes and our understanding being based mainly on cross-sectional data. Many research opportunities are present for land-use planning policies now that planning for cycling is a top priority for cities and regions across the world.
\end{abstract}

\section{Article history:}

Received: January 9, 2014

Received in revised form: August 22, 2014

Accepted: December 12, 2014

Available online: September 15, 2015

\section{Introduction}

Research, planning, and policy often combine walking and bicycling into the category "nonmotorized" transportation. In doing so, studies have provided and identified some of the roles and characteristics of nonmotorized modes within the broader realm of travel behavior. Published academic research of this kind has suggested that communities with higher densities, connectivity, and mixed-land uses positively influence nonmotorized travel (Saelens, Sallis, and Frank 2003). However, by grouping walking and bicycling together, it is assumed, perhaps errantly, that users of these separate modes have similar characteristics and demonstrate like behaviors, and the modes have commensurate relationships with the surrounding environment and serve similar needs (Krizek, Handy, and Forsyth 2009).

Walking and bicycling indeed share a few similarities. They are human-powered modes, requiring the physical capability to participate in them. Users are more exposed to the environment, including

Copyright 2015 Christopher D. Muhs \& Kelly J. Clifton

http://dx.doi.org/10.5198/jtlu.2015.727

ISSN: 1938-7849 | Licensed under the Creative Commons Attribution - Noncommercial License 3.0

The Journal of Transport and Land Use is the official journal of the World Society for Transport and Land Use (WSTLUR) and is published and sponsored by the University of Minnesota Center for Transportation Studies. This paper is also published with sponsorship from WSTLUR and the Institutes of Transportation Studies at the University of California, Davis, and the University of California, Berkeley. 
weather elements, other road users, and air pollution, than travelers using motorized modes and are more vulnerable to harm. While also true of motorized modes, active travel modes are often pursued for recreational purposes or undirected travel (Cao, Mokhtarian, and Handy 2009).

Despite this number of shared qualities, there are perhaps more significant dissimilarities between these two modes. Two of the most divergent characteristics are travel speeds and distances. Pedestrians move through space much more slowly than bicyclists: comfortable average walking speeds for healthy adults are between 4.5 and 5.3 kilometers per hour (2.8 and 3.3 miles per hour) (Bohannon 1997), whereas average bicycling speeds have been shown in GPS studies to be 16.1 kilometers per hour (10 miles per hour) in Portland, Oregon (Broach, Dill, and Gliebe 2012), and 10.1 kilometers per hour (6.3 miles per hour) in Zurich (Menghini et al. 2010). It follows that pedestrians tend to travel much shorter distances than cyclists. Many walking trips are very short segments, perhaps just a few city blocks, and are often multimodal, made in conjunction with other modes (Krizek, Handy, and Forsyth 2009).

In addition, there is more of a barrier to entry for cycling, as a bicycle and other equipment are necessary. This is accompanied by a need to store the bicycle when not traveling, requiring the provision of bike parking facilities.

Unique infrastructure distinctions for walking and cycling complicate their potential interactions with other travel modes. Pedestrians can be accommodated by sidewalks or multi-use paths, and conflict points with other modes occur mainly at intersections, except where space is shared with bicycles on multi-use paths or where legal on the sidewalk. Bicycles are also considered street-legal vehicles for most facilities and mix with both vehicles and pedestrian traffic. The differences in mixing with other modes and sharing space with other users are intuitive when considering different types of infrastructure; the bicycling experience varies considerably across the following examples:

- Bicycling among motor vehicles in a roadway with no bike-specific infrastructure

- Bicycling among vehicles in a roadway with painted "sharrows," indicating the travel lane is to be shared

- Bicycling in striped bike lanes adjacent to vehicles with no separation

- Bicycling in striped bike lanes separated from vehicles by a painted buffer

- Bicycling in a facility separated from vehicle traffic by grade, a vehicle parking lane, bollards, planters, or other physical objects.

Switching between modes is quite different for bicyclists as well. Bicycling has an immediate pedestrian element once dismounted. Riders can walk their bikes along sidewalks or through crosswalks. Boarding transit with a bicycle is also possible, as many buses and trains are equipped to store them. Bicycle racks on vehicles enable a transfer between automobile and bicycle travel as well, albeit cumbersome at times. Mode transfer for pedestrians is much simpler.

There is also a well-documented gender gap in cycling (Garrard, Handy, and Dill 2012), and there may be a greater impact of weather on cycling, in particular temperature and wind (Böcker, Dijst, and Prillwitz 2013). Further, the operational characteristics of bicyclists and facility design requirements are different than those of pedestrians (Landis et al. 2004; AASHTO 2004; AASHTO 2012).

These differences give rise to uncertainties in planning and policies directed at these modes, particularly with respect to how they might intersect with the built environment. Cities are investing more in cycling infrastructure, including bike-sharing services, and bicycling is on the rise. But there is little specific guidance for these cities as they plan for greater bicycle mode shares. The vast majority of work on how the built environment interacts with nonmotorized travel focuses largely on pedestrians (Ewing and Cervero 2010; Saelens, Sallis, and Frank 2003; Saelens and Handy 2008), and most of the cycling work is centered on infrastructure needs (Lowry et al. 2012; Winters et al. 2013). Planners must make assumptions about the densities and mix of uses necessary to support cycling, based largely on what is known about the built environment and pedestrian activity. The best practices in planning for pedes- 
trians may not produce environments that provide the highest support for bicyclists. At a minimum, planners should understand the tradeoffs that different land-use schemes may have for different modes.

To investigate this further, this paper assesses the state of the knowledge about land-use impacts on cycling and presents a case for and research agenda toward a definition of bicycle-supported development. To this end, we present a review of the relevant cycling and walking literature. The guiding questions to structure this review are:

- What built-environment characteristics are associated with cycling?

- How do they compare with those related to walking?

- Based on this review, can we define a unique definition of bicycle-oriented development?

- Where are the gaps in this definition?

Note that existing reviews have summarized the research topics of the built-environment effects on walking (i.e., Saelens and Handy 2008) and bicycling (Heinen, van Wee, and Maat 2010), but our focus is to tease out where the built-environment characteristics intersect with respect to bicycle and pedestrian needs, where the two modes diverge, and identify areas where more research is needed to support planning efforts.

\section{$2 \quad$ State of the knowledge}

The majority of studies of active travel and the built environment have walking as the focus. Hundreds of published studies on walking and the environment have been assessed in several meta-reviews (Humpel, Owen, and Leslie 2002; Saelens, Sallis, and Frank 2003; Cunningham and Michael 2004; Lee and Vernez-Moudon 2004; McCormack et al. 2004; Owen et al. 2004; Aarts and Schofield 2005; McMillan 2005; Heath et al. 2006; Saelens and Handy 2008). These studies have consistently found that density, proximity to non-residential destinations, network connectivity, and land-use mix have positive relationships with walking for transportation. Trip distance, which is related to these built form attributes, is also key.

Many other studies have combined walking and bicycling together in assessing active travel mode choice (Kitamura, Mokhtarian, and Laidet 1997; Kockelman 1997; Bento et al. 2003; Pikora et al. 2003; Rodríguez and Joo 2004; Wendel-Vos et al. 2004; Zhang 2004; Næss 2005; Soltani and Allan 2006; Cao, Mokhtarian, and Handy 2009b; Chatman 2009; Greenwald 2009; Van Acker, Mokhtarian, and Witlox 2011). Outcomes are in agreement with those of walking meta-reviews. Results generally support positive relationships between nonmotorized travel choice and population density, network connectivity, walking and bicycling infrastructure, and access to employment, transit, and certain types of non-residential destinations. However, because the distributions of the samples in the nonmotorized category are skewed heavily by pedestrians, we expect the findings to be consistent with the pedestrianonly literature.

Far fewer studies have examined travel behavior and the built environment with an explicit consideration of bicycling. The historical lack of sufficient data about cyclists' behavior has hindered progress in this area, and thus there is less evidence to compare the built-environment associations with these two modes. The increasing interest in cycling over the last 10 years has generated a host of recent studies to shed light on these questions (Muhs and Clifton 2014).

In this section, over 45 studies from travel behavior, traffic safety, and urban design literature are reviewed, and results are compared against the built-environment dimensions associated with walking. Studies with walking and bicycling as separate choice alternatives are also reviewed, findings on bicycle infrastructure are highlighted, and considerations from walkability and bikeability indices are addressed. Studies included qualitative and quantitative research and were limited to those that considered bicy- 
cling explicitly, or for many empirical mode-choice studies, considered bicycling as its own alternative. Studies that did not consider the built environment were not of interest. Studies that met these criteria were reviewed with a focus on the types of cycling being addressed, the variables and types of variables included (control and dependent variables), how the environment was measured, and the resulting outcomes. Our aim was not to describe in depth, compare, or recommend particular analysis methods.

Appendix I summarizes the resulting review of empirical studies of the built environment and bicycling. Research is categorized as either aggregate studies of cycling, disaggregate mode choice/use, or disaggregate route choice. Studies including objective and perceived measures of the environment were included. Table columns highlight the sample location and size, analysis methods, dimension of travel analyzed, and analysis variables. For studies that present multiple models, results for the final or preferred model are shown. Significant results (either $\mathrm{p}<0.05$ or $\mathrm{p}<0.1$ ) are shown in bold with the sign of the coefficient in parentheses. Insignificant variables are also shown to provide insight into the control variables used across studies. Additional studies that did not necessarily utilize statistical analysis models (i.e., most of the studies in the "Urban design" section) are cited in the text but are not included in Appendix I. Also, as has been covered elsewhere, there are strong links between bicycling and factors like socio-demographic characteristics and weather (Heinen, van Wee, and Maat 2010). The review in this paper does not emphasize or repeat them. Rather, it focuses on built-environment characteristics that can be shaped through policy.

\section{Land use}

Many aggregate studies of mode share and disaggregate studies of mode choice have tested population density as an environmental correlate of bicycling. Population or residential density is one of the most consistently significant built-environment variables in studies of walking and the environment, but it is far less consistent of a predictor of bicycling. One aggregate study found population density to be significantly and positively related to bicycle commute mode share in England and Wales (Parkin, Wardman, and Page 2008), and another found a similar positive relationship with population density and the number of bicycle commuters per county in the United States (Zahran et al. 2008). A third found a significant diminishing effect from the quadratic term (Rietveld and Daniel 2004). However, two other aggregate studies of bicycle commuting in US cities at the metropolitan statistical area level did not find any significant relationship when controlling for other variables (Baltes 1996; Dill and Carr 2003). Of these, Baltes reported a small negative bivariate correlation $(\rho=-0.1$, p-value not reported) between population density and cycling mode share for commuting trips, and Dill and Carr (2003) presented data that on our own further analysis showed an insignificant positive bivariate correlation between these variables $(\rho=0.02$, n.s.).

Similarly, disaggregate or individual-level studies have had mixed results on whether population density is associated with cycling. Some have found a significant but modest positive effect of population density on bicycle commute mode choice (Rybarczyk and Wu 2013) and levels of use (Beenackers et al. 2012), while many more have not found any relationship with population density (Frank et al. 2008; Schneider 2011; Cervero et al. 2009; Rajamani et al. 2003; Winters et al. 2010; Zhao 2014). Ferrell and Mathur (2012) found a negative relationship between population density in the destination TAZ and bicycle mode choice for work and non-work trips. Employment density has been less studied. Schneider (2011) found no relationship between cycling as a tour mode choice and destination employment density, while Zhao (2014) found a modest positive association between commuting by bike and subdistrict level employment density. Results on the link between bicycling and population or employment density are clearly mixed. 
Inconsistencies in these results between density and bicycling may be due to the methods of measurement. The metropolitan statistical area (MSA) level studies of commuting by bike in the United States (Baltes 1996; Dill and Carr 2003) measured population density of the total MSA, obviously, but MSAs are often large conurbations that contain large swaths of suburban environments. The aggregate density measure masks its variation within MSAs. This is particularly important because bicycling levels are also likely to vary substantially within any large geographic region. This may be one of the reasons no relationship was found. Of the disaggregate level studies that failed to find a significant link between bicycle mode choice and population density, all of them measured density at a scale oriented toward pedestrians; most used buffers around origins or destinations of radii less than or equal to 1000 meters (0.6 miles) (Frank et al. 2008; Cervero et al. 2009; Schneider 2011; Winters et al. 2010), Rajamani et al. (2003) used census blocks, and Zhao (2014) used sub-districts, which are analogous to census blocks. Measuring density at this scale has become the norm in studies of this kind, but we suspect that this is influenced mainly by pedestrian research, where selection of this scale is deliberately aligned with trip distances and access to destinations. The studies reviewed that did find significant associations between density and bicycling measured the density variable at larger scales of the TAZ (Ferrell and Mathur 2012) and 3-kilometer /1.9-mile buffer (Rybarczyk and Wu 2013), which are more commensurate with distances traveled by bike.

Access to destinations has also been included. These measures are present in only the disaggregate travel-behavior studies, and results are mixed. Ten studies included at least one variable related to destination types—for example, specific land uses like schools, or accessibility—compound measures of access to employment or access to retail/service destinations. Of those 10 studies, six found significant relationships with at least one destination type or accessibility measure. Utilitarian bicycling was positively associated with individuals' perceived number of recreation destinations in the home neighborhood (Beenackers et al. 2012) and with bars and drinking establishments (Muhs and Clifton 2014), and bicycling for all purposes was positively associated with the number of office/fast food/hospitals and the perceived presence of grocery shops and schools at the home neighborhood level (Vernez-Moudon et al. 2005). Bicycle mode choice was positively associated with educational uses at destinations (Winters et al. 2010), an origin accessibility to retail and services index for recreation trips (Rajamani et al. 2003), and a transit accessibility measure at the household TAZ for commuting trips (Ferrell and Mathur 2012). However, these results do not hold across other studies. No relationships have been found between cycling and the number of nearby schools, hospitals, libraries, and shopping centers (Cervero et al. 2009), perceived level of nearby shopping, "green areas," and commercial services (Plaut 2005), or retail/service accessibility (Cervero and Duncan 2003). These destination and accessibility measures have also not been included in studies as often as density and connectivity variables.

Land-use mix is another measure mainly tested in disaggregate-level studies. Of nine studies including a land-use mix measure, just two studies on commute mode choice found a significant result. One suggested that the presence of mixed land use and small retail along the route was positively associated with increased use of the bicycle to access rail transit for commuting (Appleyard 2012), while the other (Zhao 2014) indicated that a more even jobs-housing balance in the sub-district of the household (similar to a census tract geography) and the land-use entropy within a 3.5-kilometer buffer of the home increased the odds of commuting by bike. Of these studies that have found independent associations between land-use-mix measures and bicycle mode choice, there are caveats that muffle the generalizability of the findings. Appleyard's study relies on measurements along an estimated route consisting of a buffered shortest path of which there is no way to compare to an actual route, and the trip type analyzedaccess to rail rapid transit in the morning peak time period - limits the possibilities of extrapolating the findings to other trip types due to uncertainties in the consistency of influences across those behaviors. 
Zhao's use of a buffer-level measure of entropy does not lend insight into what uses combine to form the "mix" of the mixed use, and use of a district-level jobs-housing balance index limits the ability for policymakers to know whether specific types of jobs are more or less likely to contribute to increased bicycling. As such, contrary to walking, we can conclude that based on existing research, land-use mix does not appear to have a link, or at least a very strong one, with bicycle mode choice.

Regarding the uncertain connection between land-use mix and bicycling, the issue of scale of measurement seems like less of a glaring issue compared to population density. Some researchers did indeed measure land-use mix at either census block groups (Rajamani et al. 2003; Cervero et al. 2009) or small buffers of less than a mile (Frank et al. 2008; Winters et al. 2010), but others measured land-use mix at larger buffers of one mile (1.6 kilometers) (Cervero and Duncan 2003; Beenackers et al. 2012; Rybarczyk and Wu 2013) and still found no results. Perhaps more innovative route-based measures (e.g., Winters et al. 2010; Appleyard 2012) could help clarify future results. It also could be that specific land uses "matter more" for cycling than an overall mix.

\section{$4 \quad$ Networks and infrastructure}

Bicycling studies have focused much more on the importance of infrastructure than studies of walking. Aggregate studies have found positive associations between levels of bicycle commuting and the provision of bicycle lanes at the city level in the United States (Dill and Carr 2003; Nelson and Allen 1997) and Canada (Pucher and Buehler 2005), and Parkin et al. (2008) found a relationship between commuting by bike in the United Kingdom and the proportion of the bicycle network that is off-street.

Disaggregate studies on the determinants of bicycling have mixed results for infrastructure variables. Thirteen of these studies included either objective or perceived measures of the bikeway network. Significant objective measures with positive associations with cycling included bike parking spaces (Appleyard 2012), short distances to on-street bike lanes (Krizek and Johnson 2006), bike facilities density (Schneider 2011), and proportions of the network that are bike routes and off-street paths (Winters et al. 2010). In other studies, however, no significant results were found for bike parking (Muhs and Clifton 2014; Schneider 2011) or bike facilities density (Cervero et al. 2009; Rybarczyk and Wu 2013). Significant perceived measures included facilities at the workplace like changing rooms or showers (de Geus et al. 2008; Wardman, Tight, and Page 2007), the city having an off-street bike network (Handy, Xing, and Buehler 2010), bike lanes being free of obstacles (Handy, Xing, and Buehler 2010), and neighborhood amenities for jogging or cycling (Vernez-Moudon et al. 2005).

Route choice studies emphasize the importance of the provision of the bicycle network and in some cases its quality. Tilahun, Levinson, and Krizek (2007) used a stated preference survey in Minneapolis to gauge whether bicyclists have a greater preference for more separated facilities. Results indicated a hierarchy of preferences that were assessed in terms of willingness to travel an excess of time beyond the shortest path, or how far out of the way cyclists were willing to ride to travel on certain facility types. From low to high preference, the order was: undesignated bikeway with on-street parking, roadway with no bike lane and no on-street parking, roadway with bike lane and on-street parking, roadway with bike lane and no on-street parking, off-street trail. Lusk et al. (2011) found in an injury risk study in Montreal, Quebec, that bicycle volumes on cycle tracks were 2.5 times that of volumes on reference streets, indicating a preference for separated facilities.

Other stated-preference, route-choice research indicates that riders value continuity of the bike network, wider facilities, slow vehicle speeds, low vehicle volumes, and few traffic-control disturbances (Sener, Eluru, and Bhat 2009; Stinson and Bhat 2003). Revealed preference route choice work by Menghini et al. (2010) showed with GPS data that cyclists prefer routes that are marked bikeways and 
have few traffic signals. Broach, Dill, and Gliebe (2012) built upon the initial work of Menghini et al. by controlling for work vs. non-commute trips, traffic volumes, turning movements, and different types of bike infrastructure. Cyclists' non-work travel, route-choice preferences were significantly influenced by amount of turning movements (negative), the interaction between turning movements and traffic volumes (negative), bike paths (positive), bicycle boulevards (positive), traffic-volume exposure without bike lanes (negative), and bridges with bike infrastructure (positive). Significant effects were generally lessened for commute trips, when travel time is more valuable. The model agreed with the findings of Tilahun et al. (2007), as there was a preference for separated paths followed by bicycle boulevards. Striped bike lanes were preferred only when low-traffic $(<20,000$ AADT) neighborhood streets were not available, and high-traffic streets without bike lanes were least preferred. Less methodologically abstruse studies have agreed with these findings. Aultman-Hall, Hall, and Baetz's (1997) study of characteristics of chosen routes of bicycle commuters in Guelph, Ontario, agreed with differing effects of commuting vs. non-work bicycle-route choice. Cyclists in this sample preferred direct on-road routes to get to work and school over off-street paths and highlighted the need for on-street improvements to facilitate increases in bicycle commuting. Fajans and Curry (2001) presented arguments based on fundamental physics on why routes featuring many stop signs are onerous for cycling and recommended that planners consider speed continuity in neighborhood bikeway design.

Safety studies also emphasize the importance of separation in bicycle facility types. Lusk et al. (2011) determined that the relative risk of injury while bicycling on separated cycle tracks was 0.72 that of reference streets in Montreal. Teschke et al. (2012) performed an injury risk analysis on several bicycle facility types in Toronto and Vancouver and found that separated cycle tracks had the lowest risk of injury compared to reference streets. Low-traffic local streets and busy streets with bike-specific infrastructure had low injury risk as well. On-street parking, streetcar/rail tracks, and downhill grades had associations with increased injury risks. Results of these studies along with the findings of route-choice literature suggest that bicyclists strongly consider safety in their route decisions.

Network connectivity variables have a slightly stronger relationship with bicycling than do landuse variables. Eleven studies included street density, connectivity, intersection density, route directness, or block-size measures, and eight found positive associations. These discrete choice studies found that bicycle mode choice had positive relationships with the following measures:

- A pedestrian/bike factor at trip destinations based on intersection variables (Cervero and Duncan 2003)

- Intersection density at trip origins or households (Frank et al. 2008; Ferrell and Mathur 2012; Zhao 2014)

- Intersection density along routes (Winters et al. 2010)

- Connectivity measured through network intensity attributes of urban morphology ${ }^{1}$ at the home neighborhood for commuting (Rybarczyk and Wu 2013)

Two more bicycling studies (e.g., whether a person bicycles at least once a week) found that utilitarian cycling was positively related to street density (Cervero et al. 2009) and recreational cycling was also positively associated with connectivity around the home (Beenackers et al. 2012).

Trip distance and travel time is a function of network characteristics as well as the land-use characteristics reviewed in the previous section. There is much more consensus about the influence of trip distance or travel time on cycling than the built-environment measures, as longer trip distances or travel times are associated with lower use of the bicycle. Of the aggregate studies reviewed, three control for

\footnotetext{
${ }^{1}$ Urban morphology refers to the geographical field of study of patterns of cities and human settlements. For a broader explanation, see Vernez-Moudon (1997). For detailed explanation of the network intensity variables used, see Rybarczyk and Wu (2013).
} 
trip distance and two find significance. Of the route-choice studies, all four find significant relationships. Of the remaining disaggregate analyses, 18 control for either trip distance or travel time and 14 of them found a significant association.

Vehicle parking variables have also been studied empirically in stated-preference, route-choice research. Findings suggest that on-street parking is undesirable for bicycle route choice (Sener, Eluru, and Bhat 2009; Stinson and Bhat 2003). Metered on-street parking was a control variable in Schneider's (2011) work, but was not significantly related to bicycle mode choice.

\section{Empirical comparisons of walking and bicycling choice}

Our review found 12 studies using discrete choice methodologies that allowed for direct comparisons of walking and bicycling. These results, with respect to infrastructure and built environment variables, are presented in Table 1. In general, the built-environment variables tended to have more associations with walking activity across all of these studies. Density, land-use mixing, and connectivity variables are more consistently positively associated with walking in these studies than with biking. This could be due to nearly all of these studies using the same methods and scales to measure the environment for both modes. Intuitively, and as mentioned before, the scales to measure the cycling environment should be larger than those for walking.

Not shown in Table 1, however, is that the magnitudes of the impact of built environment variables

\begin{tabular}{|c|c|c|c|}
\hline Authors & $\begin{array}{c}\text { Travel Behavior } \\
\text { Dimension }\end{array}$ & Methods & Significant Walk Findings \\
\hline $\begin{array}{l}\text { Appleyard } \\
(2012)\end{array}$ & Transit access mode choice & MNL & $\begin{array}{l}\text { Route directness }(+) \text {, } \\
\text { Avg. parcel size }(-) \text {, } \\
\text { Presence of mixed-use and small retail along route (+), } \\
\% \text { of land along route in educational / religious / other } \\
\quad \text { institutional use (-), } \\
\% \text { of route along parking lot (-), } \\
\text { Trip distance (-) }\end{array}$ \\
\hline $\begin{array}{l}\text { Cervero and } \\
\text { Duncan } \\
(2003)\end{array}$ & $\begin{array}{l}\text { Bicycle mode choice; walk } \\
\text { mode choice }\end{array}$ & $\mathrm{BL}, \mathrm{FA}$ & $\begin{array}{l}\text { Land-use diversity factor at origin }(+) \text {, } \\
\text { Trip distance (-) }\end{array}$ \\
\hline $\begin{array}{l}\text { Cervero et al. } \\
(2009)\end{array}$ & $\begin{array}{l}\text { Utilitarian bicycling for } \\
>30 \text { mins per weekday; } \\
\text { utilitarian walking for }>30 \\
\text { mins per weekday }\end{array}$ & HLM & $\begin{array}{l}\text { Street density at } 500-\mathrm{m} \text { buffer }(+) \text {, } \\
\text { Street density at } 1000-\mathrm{m} \text { buffer }(+) \text {, } \\
\text { BRT station within } 1000 \mathrm{~m} \mathrm{(+)}\end{array}$ \\
\hline $\begin{array}{l}\text { Ferrell anf } \\
\text { Mathur } \\
(2012)\end{array}$ & Commute mode choice & MNL & $\begin{array}{l}\text { Household TAZ intersection density (+), } \\
\text { Trip distance (-) }\end{array}$ \\
\hline $\begin{array}{l}\text { Ferrell and } \\
\text { Mathur } \\
(2012)\end{array}$ & Non-work mode choice & MNL & $\begin{array}{l}\text { Household TAZ population density }(+) \text {, } \\
\text { Trip distance }(-)\end{array}$ \\
\hline
\end{tabular}




\begin{tabular}{|c|c|c|c|}
\hline Authors & $\begin{array}{c}\text { Travel Behavior } \\
\text { Dimension }\end{array}$ & Methods & Significant Walk Findings \\
\hline $\begin{array}{l}\text { Frank et al. } \\
(2008)\end{array}$ & $\begin{array}{l}\text { Mode choice for } \\
\text { home-based work tours }\end{array}$ & MNL & $\begin{array}{l}\text { Origin intersection density }(+), \\
\text { Origin mixed use }(+), \\
\text { Origin retail floor-area ratio }(+), \\
\text { Destination retail floor-area ratio }(+), \\
\text { Travel time }(-)\end{array}$ \\
\hline $\begin{array}{l}\text { Frank et al. } \\
\text { (2008) }\end{array}$ & $\begin{array}{l}\text { Mode choice for } \\
\text { home-based other tours }\end{array}$ & MNL & $\begin{array}{l}\text { Origin intersection density }(+), \\
\text { Origin mixed use }(+), \\
\text { Origin retail floor-area ratio }(+) \text {, } \\
\text { Travel time }(-)\end{array}$ \\
\hline $\begin{array}{l}\text { Jonnalagadda } \\
\text { et al. (2001) }\end{array}$ & Work tour mode choice & MNL & $\begin{array}{l}\text { Origin intersection density }(+), \\
\text { Origin mixed use }(+), \\
\text { Origin retail floor-area ratio }(+) \text {, } \\
\text { Travel time }(-)\end{array}$ \\
\hline $\begin{array}{l}\text { Kim and } \\
\text { Ulfarsson } \\
(2008)\end{array}$ & $2250 \mathrm{~m}(1.4 \mathrm{mi})$ & $\begin{array}{l}\text { MNL, } \\
\text { PCA }\end{array}$ & $\begin{array}{l}\text { Urban index (+), } \\
\text { Trip distance (-) }\end{array}$ \\
\hline $\begin{array}{l}\text { Krizek and } \\
\text { Johnson } \\
(2006)\end{array}$ & $\begin{array}{l}\text { Bicycle mode choice; walk } \\
\text { mode choice }\end{array}$ & $\mathrm{BL}$ & $600 \mathrm{~m}$ group) \\
\hline $\begin{array}{l}\text { Muhs and } \\
\text { Clifton (2014) }\end{array}$ & $\begin{array}{l}\text { Walk mode choice, bike } \\
\text { mode choice }\end{array}$ & $\mathrm{BL}, \mathrm{FA}$ & $\begin{array}{l}\text { Built environment factor (+), } \\
\text { Trip distance (-) }\end{array}$ \\
\hline $\begin{array}{l}\text { Rajamani et al. } \\
\text { (2003) }\end{array}$ & Mode choice & MNL & $\begin{array}{l}\text { Land-use mix }(+) \text {, } \\
\% \text { cul-de-sac streets }(-) \text {, } \\
\text { Travel time (-) }\end{array}$ \\
\hline $\begin{array}{l}\text { Schneider } \\
(2011)\end{array}$ & $\begin{array}{l}\text { Tour mode choice for } \\
\text { shopping tour }\end{array}$ & HLM & $\begin{array}{l}\text { Population density }(+) \text {, } \\
\text { Tour distance }(-)\end{array}$ \\
\hline Zhao (2014) & Commute mode choice & MNL & $\begin{array}{l}\text { Employment density (+), } \\
\text { Jobs-housing balance (-), } \\
\text { Distance to city center (-), } \\
\text { Land-use entropy (+), } \\
\text { Density of local streets (+), } \\
\text { Distance from neighborhood centroid to metro (+), } \\
\text { Density of main road/expressway crossings (-), } \\
\text { Travel time (-) }\end{array}$ \\
\hline \multicolumn{4}{|c|}{$\begin{array}{l}\text { Note: } \mathrm{BL}=\text { binary logit model, } \mathrm{HLM}=\text { multilevel/mixed logit model, } \mathrm{MNL}=\text { multinomial logit model, } \mathrm{NL}=\text { nested logit } \\
\text { model, } \mathrm{FA}=\text { factor analysis used for built-form variables, } \mathrm{PCA}=\text { principal components analysis used for built form variables. } \\
\text { "(+)" and "(-)" indicates positive or negative relationship. }\end{array}$} \\
\hline
\end{tabular}

on walking are often much larger than those with bicycling. This is also true of trip distance or travel time variables. In three US studies, the magnitudes of the trip distance coefficient for walk mode choice were more than three times those of the corresponding coefficient for bicycling (Appleyard 2012; Cervero and Duncan 2003; Ferrell and Mathur 2012).

There are also major sample size limitations in some studies shown in Table 1. Rajamani et al.'s (2003) choice model relied on 28 cyclists, Schneider (2011) had 21 in the sample, and Kim and Ulfars- 
son (2008) relied on 33 cyclists. Results from these models about bicycling behavior must be treated with caution. However, none of these researchers found more than two significant results on builtenvironment variables related to bicycle mode choice. This could be due in part to low sample sizes.

\section{$6 \quad$ Urban design}

Urban designers offer another perspective on the bicycling environment. Forsyth and Krizek (2011) argued that bicycling should be given a more central place in urban design, which has embraced pedestrian activity. This study suggests that despite the important policy, planning, and design efforts to encourage people to ride bicycles, it is also of great importance to improve the actual experience of bicycling itself. This study stresses the need for different types of facilities, including duplicate facilities along key routes, based on the varied types of cyclists. Infrastructure needs vary with skill level, age, and cycling purpose. Some bicyclists are comfortable riding quickly in mixed automobile traffic, while others need separated facilities that make operation at slower speeds pleasant and safe.

\section{$7 \quad$ Measures of bikeability}

Walkability has been a popular concept in transportation planning circles in the past decade. Informed largely by physical activity and mode-choice studies, several indices and audit tools to measure pedestrian-friendliness have been developed and their reach has often been overextended to evaluate the cycling environment. These include WalkScore ${ }^{\circledR}$ (2013), the Pedestrian Environment Factor (Parsons Brinckerhoff Quade and Douglas Inc., Cambridge Systematics Inc., and Calthorpe Associates 1993; Cambridge Systematics Inc., Parsons Brinckerhoff Quade and Douglas Inc., and S. H. Putman Associates Inc. 1996), Walkability Index (Frank and Engelke 2005), Walk Opportunities Index (Kuzmyak, Baber, and Savory 2006), Pedestrian Environment Data Scan (Clifton, Livi Smith, and Rodriguez 2007), Pedestrian Environmental Quality Index (San Francisco Department of Public Health 2008), Pedestrian Index of the Environment (Clifton et al. 2014), and others. While these indices and audits all serve particular purposes to assess walkability, they contain varying levels of limitations including imprecise or subjective measures, reproducibility concerns, lack of standardization, and limited policy sensitivity (Singleton et al. 2014). The compositions of most of these tools reflect the research findings from studies of walking and the built environment, and include measures of populations density, employment density, pedestrian network connectivity, land-use mix, and access to transit.

More recently, planners have been interested in bikeable environments as well. McNeill (2011) defined bikeability as a local accessibility measure based on destinations and bicycle infrastructure, and whether basic daily travel needs like travel to work and running errands could be done within a 20-minute bike trip. Lowry et al. (2012) defined bikeability slightly differently as "an assessment of an entire bikeway-network in terms of the ability and perceived comfort and convenience to access important destinations." Both definitions are focused on destination accessibility by bicycle.

Accordingly, compound tools to measure suitability for bicycling and bikeability have been developed for different purposes. The intent of these tools has been either for rating the comfort and safety of bike network links (see Table 2), assessing holistic existing conditions (Birk et al. 2010; Winters et al. 2013) or optimally locating future infrastructure investments (Larsen and El-Geneidy 2010).

In Freiburg, Germany, two small "eco-suburbs"—Rieselfeld and Vauban—have been developed on previous brownfield sites with the intent of catering to a housing market that prefers low-car or car-free living. Both transit-oriented development neighborhoods are about 3 kilometers (1.9 miles) from the 
city center and feature traffic calming provisions, on- and off-street bicycle facilities, frequent bus and tram transit 15 minutes), plentiful bike parking, low speed limits, mixed land uses and destination, and limited vehicle parking spots. Both are bicycle-oriented in that they have high-quality route infrastructure, marked street crossings, covered bike parking (in front of every residential building in Rieselfeld), and are well connected to the surrounding Freiburg city bicycle network, enabling easy travel to other neighborhoods in the city (Broaddus 2010). The main difference between them is vehicle parking provisions. Rieselfeld has free on-street parking and underground parking garages financed by property owners, whereas Vauban has metered and very limited on-street parking, and property owners can opt-out of paying for a parking spot in a garage if they agree to live car-free (Broaddus 2010). Despite being located within the city of Freiburg, which has a lower automobile mode share than the average in Germany, both developments feature lower automobile ownership rates and higher rates of walking, bicycling, and transit use than the surrounding city (Broaddus 2010). Obviously, most residents have opted into relocating to the districts, but the low vacancy rates in Rieselfield and Vauban demonstrate that neighborhoods oriented toward non-automobile transportation modes can be successful.

Lowry et al. (2012) provides a review of assessment tools in Table 2, and offers a method to include the effect of destinations on bikeability. The listed methods are all similar link-by-link measures based on attributes of the bike facility (e.g., surface conditions, lane widths, and vehicle volumes) that combine into a point score. Some methods are improvements of previous work and others were created from scratch. The study shows that proposed additional bicycling infrastructure and land-use changes improve the bikeability of the case study location of Moscow, Idaho. New infrastructure had the larger effect on bikeability than land-use changes, which were modest.

The tool developed by Birk et al. (2010) is based on 36 "bicycle zones" in Portland, Oregon, and

Table 2: Common bicycle suitability methods (from Lowry et al. 2012)

\begin{tabular}{|l|l|l|}
\hline \multicolumn{1}{|c|}{ Method } & \multicolumn{1}{c|}{ Acronym } & \multicolumn{1}{c|}{ Reference } \\
\hline Bicycle safety index rating & BSIR & Davis (1987) \\
\hline Bicycle stress level & BSL & Sorton and Walsh (1994) \\
\hline Road condition index & RCI & Epperson (1994) \\
\hline Interaction hazard score & HIS & Landis (1994) \\
\hline Bicycle suitability rating & BSR & Davis (1995) \\
\hline Bicycle level of service (Botma) & BLOS & Botma (1995) \\
\hline Bicycle level of service (Dixon) & BLOS & Dixon (1996) \\
\hline Bicycle suitability score & BSS & Turner et al. (1997) \\
\hline Bicycle compatibility index & BCI & Harkey et al. (1998) \\
\hline Bicycle suitability assessment & BSA & Emery and Crump (2003) \\
\hline Bicycle level of service (Jensen) & BLOS & Jensen (2007) \\
\hline Bicycle level of service (Petritsch et al) & BLOS & Petritsch et al. (2007) \\
\hline Bicycle level of service (HCM) & BLOS & HCM (2010) \\
\hline
\end{tabular}

the measurement is based on a bikeway quality index (based on vehicle speeds, vehicle volumes, number of lanes, bicycle lane drops, "difficult transitions," bicycle lane widths, jogs, pavement quality, intersection crossing quality, and number of stops), road network density, bicycle network density, permeability, connectivity, average slope, and distances to commercial establishments. While innovative, the tool relies heavily on subjective assessments by an expert panel.

Winters et al. (2013) developed a fine-grained resolution (30-meter/100-foot grid) region-wide tool to measure bikeability in Vancouver, British Columbia, based on bicycle route density, bicycle 
route separation, connectivity of bike-friendly roads, topography, and density of destinations. The study showed that the tool is positively associated with bicycle commute mode share, and the components are quite different from those in walkability indices. The composition of the tool was based on outcomes of travel behavior surveys, opinion surveys, and focus groups.

Larsen and El-Geneidy (2010) developed a 300-meter (980-foot) grid-based tool in Montreal, Quebec, for prioritizing areas in need of bike infrastructure improvements based on current bicycle trips, current short vehicle trips, segments suggested by survey respondents, bicycle crash data, and incomplete nodes on the bicycling network. Their tool relies partially on local input and requires a survey effort to reproduce. It indirectly addresses bikeability by highlighting problem areas in the bike network.

While many more bikeability tools are likely to emerge in the coming years, it is important to note that the existing ones reflect a clear difference in their composition and their evaluation criteria compared to walkability assessment tools. Not included in bikeability are land use and population or employment density measures, and more emphasis is placed on infrastructure and topography. In general, walkability tools are much more closely tied to land use. This is attributable to the lack of consistent findings between bicycling and measures of land use in existing research.

\section{Discussion: Defining a research agenda for bicycle supported development}

Highly walkable and highly bikeable environments are quite different. This paper underscores the differences in qualities between cycling and walking and punctuates the overall lack of understanding of the relationship between the built environment and use of the bicycle. Early studies of active travel mode choice and levels of walking and bicycling tended to combine nonmotorized modes together and the outcomes suggested that density, land-use mix, and connectivity positively impact the use of both modes. As data on cycling activity have become more abundant, studies have begun to segregate these nonmotorized modes, a modest literature around bicycling has emerged, and important distinctions between the two appear. Findings of these studies are much less consistent-indicating the relative differences in the importance of built environment attributes or dissonance among which attributes are associated with each mode.

As in the larger travel-behavior literature, socio-demographics, including gender and vehicle ownership/availability, often have a stronger relationship with bicycling than do built-environment variables. The review of numerous studies suggests that the land use tends to have an overall greater impact on walking activity while cyclists respond more to infrastructure and network characteristics. Walking responds to the built-environment characteristics that can be changed through land-use policy, including levels of density, mixing, and connectivity. Bicycling, on the other hand, is influenced much more by the quality of the network, its completeness and connectivity, level of separation, and grade. However, these general statements have important nuances and beg for a more robust research agenda around cycling and the built environment so that we can determine what constitutes bicycle-supported development.

Based on the review conducted in this study, details of our proposed research agenda are enumerated below. This includes issues of measurement, methods, and data, presented by "themes" of future research needs.

\subsection{Non-linear and minimum/maximum relationships with density}

This review suggests that land-use characteristics have performed inconsistently in studies of cycling. There is a lack of consensus on the impact of density, access to destinations, and land-use mixing. These 
relationships may be non-linear, particularly with respect to density, and only one study has tested nonlinear measures (Rietveld and Daniel 2004). Cycling may also be sensitive to minimum and maximum thresholds. For example, high-density locations correlated with central business districts, downtowns, and regional centers may not provide environments conducive to cycling. The greater intersection densities and traffic control often mean more stops, slowing travel speeds. Because origins and destinations are close, walking becomes a more competitive mode, particularly when parking and/or cycling infrastructure is not provided. In addition, these locations often have high volumes of mixed traffic, including high volumes of pedestrians, automobiles, and transit. Rail transit offers its own safety considerations as on-street rail tracks are often the cause of bicycle crashes. Finally, these high-density locations tend to have smaller housing units, which may lack adequate storage for bicycles at home leading to lower bicycle ownership rates for residents. On the other end of the spectrum, low-density environments may not provide destinations within a reasonable distance for utilitarian cycling but may offer better recreational opportunities, begging for studies of the built environment to separate cycling by trip purpose. Cycling may thrive in lower-density environments than pedestrians, but studies need to test this assertion and gather more evidence.

\subsection{Different scales of measurement}

While the ability of cyclists to travel at faster speeds than pedestrians is widely acknowledged, this has not often translated into built-environment measures computed at spatial scales equivalent to this travel time differential. Distance and travel time, which are critical factors in pedestrian behavior, have also been shown to be significant factors related to cycling. Perhaps the inconsistent performance of land-use characteristics in bicycling research explained above is related to the differences in travel speeds. Many researchers tested pedestrian-scale, built-environment data (e.g., 800-meter or 0.5-mile buffers around place of residence to measure population density) on bicyclists, and this could relate to the lack of findings. This is also true of measures of local accessibility or access to destinations. As such, larger scales based on bicycling distances and travel times should be tested in measuring land-use characteristics. The insignificance of mixed land use across cycling research also suggests that more attention be given to what types of destinations are considered in the mix. Corridor and route-level measures should also be further explored (e.g. Winters et al. 2010; Appleyard 2012). Current measures of this kind have been based on buffered shortest paths, and the emergence of more route data is sure to aid in refining them.

\subsection{Improved network representation}

As for network characteristics and infrastructure needs, there is much more agreement across studies. In part, this may be a result of researchers placing more emphasis on this aspect and because the landuse measures may be computed at an inappropriate scale. The bicycle-route-choice literature indicates strong preferences toward separated bicycle facilities, low vehicle-traffic volumes, reduced traffic control instances, and fewer conflicts with vehicles. The bicycle safety literature emphasizes the importance of reducing conflict points with vehicles and increasing separation from vehicles with respect to injury risks. Despite increased distance and travel time being consistently negatively associated with bicycle use, there is evidence to support the notion that cyclists are willing to trade off travel time for the safety and comfort provided by separated facilities. A hierarchy of facility preferences has emerged. As more cities are investing in separated facilities (Green Lane Project 2013), more study is needed to understand how cyclists and other transportation system users are responding to this infrastructure, which lacks detailed and tested design guidelines for implementation in US contexts. 


\subsection{Different users and data}

Unlike pedestrians and to a certain extent drivers, level of cycling experience plays a role in facility preference and behavior (Forsyth and Krizek 2011; Dill and McNeil 2013; Damant-Sirois, Grimsrud, and El-Geneidy, accepted). Based on Schneider's Theory of Routine Mode Choice Decisions (2013), basic safety and security (from traffic and crime) are more important to individuals than convenience or cost, but that awareness and availability of the option trumps both. For cycling, this suggests that well-placed separated facilities are a great option and may be necessary for cities to attract more users.

It has also been acknowledged that cyclists may be more multimodal than other travelers, due to weather or other situational constraints (Heinen, Maat, and van Wee 2011; Gatersleben and Haddad 2010; Damant-Sirois, Grimsrud, and El-Geneidy, accepted). Nearly all of the literature we reviewed consisted of cross-sectional studies, with individuals observed at just one point in time. The lack of longitudinal studies on bicycling makes us raise the question: Is our current understanding of cycling behavior based on a slim percentage of the overall cycling population? In most cases, there is no way to know, since data on modal variability were not gathered. More study is needed to examine these travel patterns over time. More stated-preference research could help answer these questions.

There are also synergies between bicycle and transit modes, including substitution (mode switching) and complementary effects (e.g., bike-to-transit travel) that warrant more study (Singleton and Clifton 2014). This is especially important for evaluating sustainability policies and goals as well as the emergence of bike share. If bike share is drawing a majority of users away from bus and rail (Fishman, Washington, and Haworth 2013), maybe planners should reconsider it as a public transit mode

\subsection{Urban design elements}

Urban designers have postulated the importance of improving the bicycling experience. The unique qualities of the experience include speed, movement, and momentum, which are distinct from automobile- or pedestrian-oriented design criteria. There is little work in the United States with respect to design and more attention needs to be given on how to enhance the cycling experience and integrate this with the urban landscape. The site design of destinations often lacks consideration of cycling and where amenities such as bicycle parking are included, it is often an afterthought.

\section{$9 \quad$ Limitations and final thoughts}

This study does have limitations and comparing results across these studies must be done with caution. The built environment is measured differently in most studies, with varying spatial scales and units. Most studies have examined household, origin, and/or destination built environments, and more recent research has focused on route built environments. Some control for explicit built-environment measures independently, whereas others use statistical techniques like factor analysis or principal components analysis to combine variables together to bypass multicollinearity issues. Further, the dimension of travel behavior is different in many of these papers. While all of the studies analyzed mode choice or mode use, some analyzed recreational versus utilitarian travel, some analyzed commuting, while others assessed non-work travel, and the choice sets in discrete choice studies were rarely the same.

To date, existing research on bicycling is focused largely on urban areas and recreational locations that can gather large enough sample sizes, which has limited them to mainly Canadian and western US cities or international cycling cities that differ in context substantially from those in North America. As cycling is becoming more popular, future studies will be better equipped to test the built environment 
correlates with bicycling across a variety of area types and characteristics of cyclists and will face less sample size issues. With more attention to the unique characteristics of cycling, this more robust research agenda around defining bicycle-supported development can provide better guidance to engineers, planners, and urban designers as they shape the built environment.

\section{References}

Aarts, H., and G. Schofield. 2005. Transport, urban design, and physical activity: An evidence-based update. Transportation Research Part D: Transport and Environment 10 (3): 177-196. doi:10.1016/j. $\operatorname{trd} .2004 .12 .001$.

Akar, G., and K. J. Clifton. 2009. Influence of individual perceptions and bicycle infrastructure on decision to bike. Transportation Research Record 2140: 165-172. doi:10.3141/2140-18.

American Association of State Highway Transportation Officials (AASHTO). 2004. Guide for the Planning, Design, and Operation of Pedestrian Facilities. Washington, DC: AASHTO.

American Association of State Highway Transportation Officials (AASHTO). 2012. Guide for the Development of Bicycle Facilities. 4th edition. Washington, DC: AASHTO.

Appleyard, B. 2012. Sustainable and healthy travel choices and the built environment. Transportation Research Record 2303: 38-45. doi:10.3141/2303-05.

Aultman-Hall, L., F. Hall, and B. Baetz. 1997. Analysis of bicycle commuter routes using geographic information systems: Implications for bicycle planning. Transportation Research Record 1578: 102110. doi:10.3141/1578-13.

Baltes, M. 1996. Factors influencing nondiscretionary work trips by bicycle determined from 1990 U.S. Census metropolitan statistical area data. Transportation Research Record 1538: 96-101. doi:10.3141/1538-13.

Beenackers, M. A., S. Foster, C. B. M. Kamphuis, S. Titze, M. Divitini, M. Knuiman, F. J. van Lenthe, and B. Giles-Corti. 2012. Taking up cycling after residential relocation: Built environment factors. American Journal of Preventive Medicine 42(6): 610-15. doi:10.1016/j.amepre.2012.02.021.

Bento, A., M. Cropper, A. Mobarak, and K. Vinha. 2003. The Impact of Urban Spatial Structure on Travel Demand in the United States. Washington, DC: World Bank. Url: http://www-wds.worldbank.org/servlet/WDSContentServer/WDSP/IB/2003/04/23/000094946_03040404262857/ Rendered/PDF/multi0page.pdf.

Birk, M., K. Voros, M. Rose, R. Geller, D. Igarta, and B. Patterson. 2010. Cycle zone analysis: An innovative approach to bicycle planning. Presented at the 89th Annual Meeting of the Transportation Research Board, January 10-14, 2010, Washington, DC.

Böcker, L., M. Dijst, and J. Prillwitz. 2013. Impact of everyday weather on individual daily travel behaviours in perspective: A literature review. Transport Reviews 33(1): 71-91. doi:10.1080/0144164 7.2012.747114.

Bohannon, R. W. 1997. Comfortable and maximum walking speed of adults aged 20-79 years: Reference values and determinants. Age and Ageing 26(1): 15-19. doi:10.1093/ageing/26.1.15.

Botma, H. 1995. Method to determine level of service for bicycle paths and pedestrian-bicycle paths. Transportation Research Record 1502: 38-44.

Broach, J., J. Dill, and J. Gliebe. 2012. Where do cyclists ride? A route choice model developed with revealed preference GPS data. Transportation Research Part A: Policy and Practice 46(10): 1730-40. doi:10.1016/j.tra.2012.07.005.

Broaddus, A. 2010. Tale of two ecosuburbs in Freiburg, Germany. Transportation Research Record 2187: 114-122. doi:10.3141/2187-15. 
Cambridge Systematics Inc., Parsons Brinckerhoff Quade and Douglas Inc., and S. H. Putman Associates Inc. 1996. Making the Land Use Transportation Air Quality Connection: Model Modifications. Volume 4, Part 2. Portland, OR: 1000 Friends of Oregon. http://content.lib.utah.edu/utils/getfile/ collection/FHWA/id/1404/filename/1405.pdf.

Cao, X., P. L. Mokhtarian, and S. L. Handy. 2009a. No particular place to go: An empirical analysis of travel for the sake of travel. Environment and Behavior 41(2): 233-257. doi:10.1177/0013916507310318.

Cao, X., P. L. Mokhtarian, and S. L. Handy. 2009b. The relationship between the built environment and nonwork travel: A case study of northern California. Transportation Research Part A: Policy and Practice 43(5): 548-559. doi:10.1016/j.tra.2009.02.001.

Cervero, R., and M. Duncan. 2003. Walking, bicycling, and urban landscapes: Evidence from the San Francisco bay area. American Journal of Public Health 93(9): 1478-1483. doi: 10.2105/ AJPH.93.9.1478

Cervero, R., O. L. Sarmiento, E. Jacoby, L. F. Gomez, and A. Neiman. 2009. Influences of built environments on walking and cycling: Lessons from Bogotá. International Journal of Sustainable Transportation 3(4): 203-26. doi:10.1080/15568310802178314.

Chatman, D. G. 2009. Residential choice, the built environment, and nonwork travel: Evidence using new data and methods. Environment and Planning A 41(5): 1072-89. doi:10.1068/a4114.

Clifton, K. J., A. D. Livi Smith, and D. Rodriguez. 2007. The development and testing of an audit for the pedestrian environment. Landscape and Urban Planning 80(1-2): 95-110. doi:10.1016/j. landurbplan.2006.06.008.

Clifton, K. J., P. A. Singleton, C. D. Muhs, R. J. Schneider, and P. Lagerwey. 2014. Improving the Representation of the Pedestrian Environment in Travel Demand Models: Phase I. Project Report OTRECRR-13-08. Portland, OR: Oregon Transportation Research and Education Consortium (OTREC). Url: http://trec.pdx.edu/research/project/510.

Cunningham, G., and Y. L. Michael. 2004. Concepts guiding the study of the impact of the built environment on physical activity for older adults: A review of the literature. American Journal of Health Promotion 18(6): 435-43. doi:10.4278/0890-1171-18.6.435.

Damant-Sirois, G., M. Grimsrud, and A. El-Geneidy. 2014. What's your type: A multidimensional cyclist typology. Transportation 41: 1153-1169. doi:10.1007/s11116-014-9523-8.

Davis, W. J. 1987. Bicycle safety evaluation. PhD dissertation. Auburn, AL: Auburn University.

Davis, W. J. 1995. Bicycle test route evaluation for urban road conditions. Presented at the ASCE Transportation Congress: Civil Engineers-Key to the World of Infrastructure, October 22-26, 1995, San Diego, CA.

De Geus, B., I. de Bourdeaudhuij, C. Jannes, and R. Meeusen. 2008. Psychosocial and environmental factors associated with cycling for transport among a working population. Health Education Research 23(4): 697-708. doi:10.1093/her/cym055.

Dill, J., and T. Carr. 2003. Bicycle commuting and facilities in major US cities: If you build them, commuters will use them. Transportation Research Record 1828: 116-123. doi:10.3141/1828-14.

Dill, J., and N. McNeil. 2013. Four types of cyclists? Examining a typology to better understand bicycling behavior and potential. Presented at the 92nd Annual Meeting of the Transportation Research Board, January 13-17, 2013, Washington, DC.

Dixon, L. 1996. Bicycle and pedestrian level-of-service performance measures and standards for congestion management systems. Transportation Research Record 1538: 1-9. doi:10.3141/1538-01.

Emery, J., and C. Crump. 2003. The WABSA Project: Assessing and Improving your Community's Walkability and Bikeability. Chapel Hill, NC: University of North Carolina.

Epperson, B. 1994. Evaluating suitability of roadways for bicycle use: Toward a cycling level-of-service 
standard. Transportation Research Recond 1438: 9-16.

Ewing, R., and R. Cervero. 2010. Travel and the built environment. Journal of the American Planning Association 76(3): 265-294.

Fajans, J., and M. Curry. 2001. Why bicyclists hate stop signs. ACCESS Magazine 1(18): 28-31. Url: http://escholarship.org/uc/item/39h8k0x9.

Ferrell, C., and S. Mathur. 2012. Influences of neighborhood crime on mode choice. Transportation Research Record 2320: 55-63. doi:10.3141/2320-07.

Fishman, E., S. Washington, and N. Haworth. 2013. Bike share: A synthesis of the literature. Transport Reviews 33(2): 148-165. doi:10.1080/01441647.2013.775612.

Forsyth, A., and K. Krizek. 2011. Urban design: Is there a distinctive view from the bicycle? Journal of Urban Design 16(4): 531-549. doi:10.1080/13574809.2011.586239.

Frank, L. D., M. Bradley, S. Kavage, J. Chapman, and T. K. Lawton. 2008. Urban form, travel time, and cost relationships with tour complexity and mode choice. Transportation 35(1): 37-54.

Frank, L. D., and P. O. Engelke. 2005. Multiple impacts of the built environment on public health: Walkable places and the exposure to air pollution. International Regional Science Review 28(2): 193216. doi: $10.1177 / 0160017604273853$.

Garrard, J., S. Handy, and J. Dill. 2012. Women and cycling. In City Cycling, J. Pucher and R. Buehler, eds., pp. 211-233. Cambridge, MA: MIT Press.

Gatersleben, B., and H. Haddad. 2010. Who Is the typical bicyclist? Transportation Research Part F: Traffic Psychology and Behavior 13(1): 41-48. doi:10.1016/j.trf.2009.10.003.

Green Lane Project. 2013. Innovative Urban Bikeway Design: A Survey of Cities. City, State: Publisher Url: http://www.bikesbelong.oli.us/usdotreport.pdf.

Greenwald, M. J. 2009. SACSIM Modeling-Elasticity Results (draft). Fehr and Peers Associates.

Handy, S. L., Y. Xing, and T. J. Buehler. 2010. Factors associated with bicycle ownership and use: A study of six small US cities. Transportation 37(6): 967-985.

Harkey, D., D. Reinfurt, and M. Knuiman. 1998. Development of the bicycle compatibility index. Transportation Research Record 1636: 13-20. doi:10.3141/1636-03.

Heath, G. W., R. C. Brownson, J. Kruger, R. Miles, K. E. Powell, and L. T. Ramsey. 2006. The effectiveness of urban design and land use and transport policies and practices to increase physical activity: A systematic review. Journal of Physical Activity and Health 3: S55.

Heinen, E., K. Maat, and B. van Wee. 2011. Day-to-day choice to commute or not by bicycle. Transportation Research Record 2230: 9-18. doi:10.3141/2230-02.

Heinen, E., B. van Wee, and K. Maat. 2010. Commuting by bicycle: An overview of the literature. Transport Reviews 30(1): 59-96. doi:10.1080/01441640903187001.

Highway Capacity Manual. 2010. Washington, D.C.: Transportation Research Board of the National Academies.

Humpel, N., N. Owen, and E. Leslie. 2002. Environmental factors associated with adults' participation in physical activity: A review. American Journal of Preventive Medicine 22(3): 188-99. doi:10.1016/ S0749-3797(01)00426-3.

Jensen, S. 2007. Pedestrian and bicyclist level of service on roadway segments. Transportation Research Record 2031: 43-51. doi:10.3141/2031-06.

Jonnalagadda, N., J. Freedman, W. A. Davidson, and J. D. Hunt. 2001. Development of microsimulation activity-based model for San Francisco: Destination and mode choice models. Transportation Research Record 1777: 25-35. doi:10.3141/1777-03.

Kim, S., and G. F. Ulfarsson. 2008. Curbing automobile use for sustainable transportation: Analysis of mode choice on short home-based trips. Transportation 35(6): 723-737. doi:10.1007/s11116-008- 
$9177-5$

Kitamura, R., P. L. Mokhtarian, and L. Laidet. 1997. A micro-analysis of land use and travel in five neighborhoods in the San Francisco bay area. Transportation 24(2): 125-158.

Kockelman, K. 1997. Travel behavior as function of accessibility, land-use mixing, and land-use balance: Evidence from San Francisco bay area. Transportation Research Record 1607: 116-25. doi:10.3141/1607-16.

Krizek, K. J., S. L. Handy, and A. Forsyth. 2009. Explaining changes in walking and bicycling behavior: Challenges for transportation research. Environment and Planning B: Planning and Design 36: $725-740$.

Krizek, K. J., and P. J. Johnson. 2006. Proximity to trails and retail: Effects on urban cycling and walking. Journal of the American Planning Association 72(1): 33-42. doi:10.1080/01944360608976722.

Kuzmyak, J. R., C. Baber, and D. Savory. 2006. Use of walk opportunities index to quantify local accessibility. Transportation Research Record 1977: 145-53. doi:10.3141/1977-19.

Landis, B., T. Petritsch, H. Huang, and A. Do. 2004. Characteristics of emerging road and trail users and their safety. Transportation Research Record 1878: 131-39. doi:10.3141/1878-16.

Landis, B. W. 1994. Bicycle interaction hazard score: A theoretical model. Transportation Research Record 1438: 3-8.

Larsen, J., and A. El-Geneidy. 2010. Build it but where? A GIS methodology for guiding the planning of new cycling facilities. Presented at the 89th Annual Meeting of the Transportation Research Board, January 10-14, 2010, Washington, DC.

Lee, C., and A. Vernez-Moudon. 2004. Physical activity and environment research in the health field: Implications for urban and transportation planning practice and research. Journal of Planning Literature 19(2): 147-81. doi:10.1177/0885412204267680.

Lowry, M. B., D. Callister, M. Gresham, and B. Moore. 2012. Assessment of communitywide bikeability with bicycle level of service. Transportation Research Record 2314: 41-48. doi:10.3141/2314-06.

Lusk, A. C., P. G. Furth, P. Morency, L. F. Miranda-Moreno, W. C. Willett, and J. T. Dennerlein. 2011. Risk of injury for bicycling on cycle tracks versus in the street. Injury Prevention 17(2): 131-135. doi:10.1136/ip.2010.028696.

McCormack, G., B. Giles-Corti, A. Lange, T. Smith, K. Martin, and T. J. Pikora. 2004. An update of recent evidence of the relationship between objective and self-report measures of the physical environment and physical activity behaviours. Journal of Science and Medicine in Sport 7(1, Supplement 1): 81-92. doi:10.1016/S1440-2440(04)80282-2.

McMillan, T. E. 2005. Urban form and a child's trip to school: The current literature and a framework for future research. Journal of Planning Literature 19(4): 440-456. doi:10.1177/0885412204274173.

McNeil, N. 2011. Bikeability and the 20-min neighborhood. Transportation Research Record 2247: 5363. doi:10.3141/2247-07.

Menghini, G., N. Carrasco, N. Schüssler, and K. W. Axhausen. 2010. Route choice of cyclists in Zurich. Transportation Research Part A: Policy and Practice 44(9): 754-765. doi:10.1016/j.tra.2010.07.008.

Muhs, C. D., and K. J. Clifton. 2014. Bicycling is different: Built environment relationships to nonwork travel. Presented at the 93rd Annual Meeting of the Transportation Research Board, January 12-16, 2014, Washington, DC.

Næss, P. 2005. Residential location affects travel behavior-but how and why? The case of Copenhagen metropolitan area. Progress in Planning 63(2): 167-257.

Nelson, A., and D. Allen. 1997. If you build them, commuters will use them: Association between bicycle facilities and bicycle commuting. Transportation Research Record 1578: 79-83. doi:10.3141/157810 . 
Owen, N., N. Humpel, E. Leslie, A. Bauman, and J. F. Sallis. 2004. Understanding environmental influences on walking: Review and research agenda. American Journal of Preventive Medicine 27(1): 67-76. doi:10.1016/j.amepre.2004.03.006.

Parkin, J., M. Wardman, and M. Page. 2008. Estimation of the determinants of bicycle mode share for the journey to work using census data. Transportation 35(1): 93-109. doi:10.1007/s11116-0079137-5.

Parsons Brinckerhoff Quade and Douglas Inc., Cambridge Systematics Inc., and Calthorpe Associates. 1993. Making the Land Use Transportation Air Quality Connection: The Pedestrian Environment. Volume 4A. Portland, OR: 1000 Friends of Oregon. http://ntl.bts.gov/DOCS/tped.html.

Petritsch, T., B. Landis, H. Huang, P. McLeod, D. Lamb, W. Farah, and M. Guttenplan. 2007. Bicycle level of service for arterials. Transportation Research Record 2031: 34-42. doi:10.3141/2031-05.

Pikora, T., B. Giles-Corti, F. Bull, K. Jamrozik, and R. Donovan. 2003. Developing a framework for assessment of the environmental determinants of walking and cycling. Social Science and Medicine 56(8): 1693-1703. doi:10.1016/S0277-9536(02)00163-6.

Plaut, P. O. 2005. Non-motorized commuting in the US. Transportation Research Part D: Transport and Environment 10(5): 347-356. doi:10.1016/j.trd.2005.04.002.

Pucher, J., and R. Buehler. 2005. Cycling trends and policies in Canadian cities. World Transport Policy and Practice 11(1): 43-61.

Pucher, J., and R. Buehler. 2006. Why Canadians cycle more than Americans: A comparative analysis of bicycling trends and policies. Transport Policy 13(3): 265-279. doi:10.1016/j.tranpol.2005.11.001.

Rajamani, J., C. Bhat, S. Handy, G. Knaap, and Y. Song. 2003. Assessing impact of urban form measures on nonwork trip mode choice after controlling for demographic and level-of-service effects. Transportation Research Record 1831: 158-165.

Rietveld, P., and V. Daniel. 2004. Determinants of bicycle use: Do municipal policies matter? Transportation Research Part A: Policy and Practice 38(7): 531-550. doi:10.1016/j.tra.2004.05.003.

Rodríguez, D. A., and J. Joo. 2004. The relationship between non-motorized mode choice and the local physical environment. Transportation Research Part D: Transport and Environment 9(2): 151-173. doi:10.1016/j.trd.2003.11.001.

Rybarczyk, G., and C. Wu. 2013. Examining the impact of urban morphology on bicycle mode choice. Environment and Planning B: Planning and Design 40(2): 272-288. Url: http://www.envplan.com/ abstract.cgi?id=b37133.

Saelens, B. E., and S. L. Handy. 2008. Built environment correlates of walking: A review. Medicine and Science in Sports and Exercise 40(7): 550-566.

Saelens, B. E., J. F. Sallis, and L. D. Frank. 2003. Environmental correlates of walking and cycling: Findings from the transportation, urban design, and planning literatures. Annals of Behavioral Medicine 25(2): 80-91.

San Francisco Department of Public Health. 2008. The Pedestrian Environmental Quality Index (PEQI): An Assessment of the Physical Condition of Streets and Intersections. Draft Methods Report. Program on Health, Equity and Sustainability, Environmental Health Section. San Francisco: SF Department of Public Health.

Schneider, R. J. 2013. Theory of routine mode choice decisions: An operational framework to increase sustainable transportation. Transport Policy 25: 128-137.

Schneider, R. J. 2011. Understanding sustainable transportation choices: Shifting routine automobile travel to walking and bicycling, PhD dissertation. Berkeley, CA: University of California. Url: http:// www.escholarship.org/uc/item/06v2g6dh.

Sener, I. N., N. Eluru, and C. R. Bhat. 2009. An analysis of bicycle route choice preferences in Texas 
US. Transportation 36(5): 511-539. doi:10.1007/s11116-009-9201-4.

Singleton, P. A., R. J. Schneider, C. D. Muhs, and K. J. Clifton. 2014. The pedestrian index of the environment (PIE): Representing the walking environment in planning applications. Presented at the 93rd Annual Meeting of the Transportation Research Board, January 12-16, 2014, Washington, DC.

Singleton, P. A, and K. J. Clifton. 2014. Exploring synergy in bicycle and transit use: Empirical evidence at two scales. Presented at the 93rd Annual Meeting of the Transportation Research Board, January 12-16, 2014, Washington, DC.

Soltani, A., and A. Allan. 2006. Analyzing the impacts of microscale urban attributes on travel: Evidence from suburban Adelaide, Australia. Journal of Urban Planning and Development 132(3): 132-137. doi:10.1061/(ASCE)0733-9488(2006)132:3(132).

Sorton, A., and T. Walsh. 1994. Bicycle stress level as a tool to evaluate urban and suburban bicycle compatibility. Transportation Research Record 1438: 17-24.

Stinson, M., and C. Bhat. 2003. Commuter bicyclist route choice: Analysis using a stated preference survey. Transportation Research Record 1828: 107-115. doi:10.3141/1828-13.

Teschke, K., M. A. Harris, C. C. Reynolds, M. Winters, S. Babul, M. Chipman, M. D. Cusimano, et al. 2012. Route infrastructure and the risk of injuries to bicyclists: A case-crossover study. American Journal of Public Health 102(12): 2336-2343. doi:10.2105/AJPH.2012.300762.

Tilahun, N. Y., D. M. Levinson, and K. J. Krizek. 2007. Trails, lanes, or traffic: Valuing bicycle facilities with an adaptive stated preference survey. Transportation Research Part A: Policy and Practice 41(4): 287-301. doi:10.1016/j.tra.2006.09.007.

Turner, S., C. Shafer, and W. Stewart. 1997. Bicycle Suitability Criteria for State Roadways in Texas. Research Report 3988-S. College Station, TX: Texas Department of Transportation, Texas A\&M University.

Van Acker, V., P. Mokhtarian, and F. Witlox. 2011. Going soft: On how subjective variables explain modal choices for leisure travel. European Journal of Transport and Infrastructure Research 11(2): 115146.

Vernez-Moudon, A. 1997. Urban morphology as an emerging interdisciplinary field. Urban Morphology 1(1): 3-10.

Vernez-Moudon, A., C. Lee, A. D. Cheadle, C. W. Collier, D. Johnson, T. L. Schmid, and R. D. Weather. 2005. Cycling and the built environment, a US perspective. Transportation Research Part D: Transport and Environment 10(3): 245-261. doi:10.1016/j.trd.2005.04.001.

WalkScore. 2013. WalkScore. http://www.walkscore.com.

Wardman, M., M. Tight, and M. Page. 2007. Factors influencing the propensity to cycle to work. Transportation Research Part A: Policy and Practice 41(4): 339-350. doi:10.1016/j.tra.2006.09.011.

Wendel-Vos, G. C. W., A. J. Schuit, R. De Niet, H. C. Boshuizen, W. Saris, and D. Kromhout. 2004. Factors of the physical environment associated with walking and bicycling. Medicine and Science in Sports and Exercise 36(4): 725-730.

Winters, M., M. Brauer, E. M. Setton, and K. Teschke. 2010. Built environment influences on healthy transportation choices: Bicycling versus driving. Journal of Urban Health 87(6): 969-993. doi:10.1007/s11524-010-9509-6.

Winters, M., M. Brauer, E. M. Setton, and K. Teschke. 2013. Mapping bikeability: A spatial tool to support sustainable travel. Environment and Planning B: Planning and Design 40(5): 865-883. doi:10.1068/b38185.

Zahran, S., S. D. Brody, P. Maghelal, A. Prelog, and M. Lacy. 2008. Cycling and walking: Explaining the spatial distribution of healthy modes of transportation in the United States. Transportation Re- 
search Part D: Transport and Environment 13(7): 462-470. doi:10.1016/j.trd.2008.08.001.

Zhang, M. 2004. The role of land use in travel mode choice: Evidence from Boston and Hong Kong. Journal of the American Planning Association 70(3): 344-360.

Zhao, P. 2014. The impact of the built environment on bicycle commuting: Evidence from Beijing. Urban Studies 51(5): 1019-1037. doi:10.1177/0042098013494423. 


\begin{tabular}{|c|c|c|c|c|c|c|}
\hline Authors & Sample & $\begin{array}{c}\text { Travel Behavior } \\
\text { Dimension }\end{array}$ & Methods & $\begin{array}{l}\text { Built Form } \\
\text { Variables }\end{array}$ & $\begin{array}{c}\text { Bicycle } \\
\text { Infrastructure } \\
\text { Variables }\end{array}$ & Other Variables \\
\hline \multicolumn{7}{|c|}{ Aggregate bicycling studies } \\
\hline $\begin{array}{l}\text { Baltes } \\
(1996)\end{array}$ & $\begin{array}{l}\text { United States: } \\
\text { Census } \\
\text { data in } 284 \\
\text { metropolitan } \\
\text { statistical areas }\end{array}$ & $\begin{array}{l}\text { Bicycle commute } \\
\text { mode share }\end{array}$ & OLS & $\begin{array}{l}\text { Population density, } \\
\% \text { of workers working } \\
\text { in central } \\
\text { city, } \\
\% \text { of workers living } \\
\text { in central city (+), } \\
\% \text { of population } \\
\text { living in central } \\
\text { city (-) }\end{array}$ & None & $\begin{array}{l}\% \text { Asian population (+), } \\
\% \text { Hispanic population, } \\
\% \text { Black population, } \\
\% \text { non-white population, } \\
\% \text { population in armed forces, } \\
\% \text { population aged } 16-29, \\
\% \text { population aged } \mathbf{1 8 - 2 4} \text { in school (+), } \\
\% \text { population in high school, } \\
\text { Median household income, } \\
\% \text { unemployed (+), } \\
\% \text { employed in agriculture (+), } \\
\% \text { below poverty level, } \\
\% \text { females aged over } 16 \text { in workforce, } \\
\% \text { households with zero vehicles (+), } \\
\% \text { with travel time to work <10 minutes, } \\
\% \text { owner-occupied households (-) }\end{array}$ \\
\hline $\begin{array}{l}\text { Dill and } \\
\text { Carr (2003) }\end{array}$ & $\begin{array}{l}\text { United States: } \\
\text { Census } \\
\text { commuting } \\
\text { data in } 42 \\
\text { large cities }\end{array}$ & $\begin{array}{l}\text { Bicycle commute } \\
\text { mode share }\end{array}$ & OLS & $\begin{array}{l}\% \text { of workers } \\
\text { working in central } \\
\text { city, }\end{array}$ & $\begin{array}{l}\text { Avg. annual } \\
\text { state spending } \\
\text { per capita } \\
\text { on bicycle/ } \\
\text { pedestrian } \\
\text { improvements } \\
(+), \\
\text { Bike lanes per } \\
\text { square mile }(+)\end{array}$ & $\begin{array}{l}\% \text { population that are university } \\
\text { students, } \\
\% \text { workers by industry category, } \\
\% \text { workers by occupation category: } \\
\text { farming or forestry (+), } \\
\text { Avg. vehicles per household (-), } \\
\% \text { of households with zero vehicles, } \\
\text { Transit availability, } \\
\text { Avg. gasoline price, } \\
\text { Median income, } \\
\% \text { of adults in poverty, } \\
\text { Avg. annual days of rainfall (-), } \\
\text { Avg. annual precipitation }\end{array}$ \\
\hline $\begin{array}{l}\text { Nelson } \\
\text { and Allen } \\
(1997)\end{array}$ & $\begin{array}{l}\text { United States: } \\
\text { Commuting } \\
\text { data in } 18 \\
\text { cities }\end{array}$ & $\begin{array}{l}\text { Bicycle commute } \\
\text { mode share }\end{array}$ & OLS & $\begin{array}{r}\% \text { of workers living } \\
\text { in central city }(+)\end{array}$ & $\begin{array}{l}\text { Bike pathways } \\
\text { per capita (+) } \\
\text { (bike lanes, } \\
\text { separated } \\
\text { facilities, or } \\
\text { off-street } \\
\text { paths) }\end{array}$ & $\begin{array}{l}\text { Steep terrain, } \\
\text { Annual no. days with > } 2.5 \text { mm }(0.1 \text { in) } \\
\text { precipitation (-), } \\
\text { Avg. high temperature, } \\
\% \text { college students }\end{array}$ \\
\hline
\end{tabular}




\begin{tabular}{|c|c|c|c|c|c|c|}
\hline Authors & Sample & $\begin{array}{c}\text { Travel Behavior } \\
\text { Dimension }\end{array}$ & Methods & $\begin{array}{l}\text { Built Form } \\
\text { Variables }\end{array}$ & $\begin{array}{c}\text { Bicycle } \\
\text { Infrastructure } \\
\text { Variables }\end{array}$ & Other Variables \\
\hline $\begin{array}{l}\text { Parkin et al. } \\
\text { (2008) }\end{array}$ & $\begin{array}{l}\text { England and } \\
\text { Wales: } \\
\text { unreported } \\
\text { number of } \\
\text { commuters } \\
\text { aged 16-74 in } \\
1111 \text { electoral } \\
\text { wards }\end{array}$ & $\begin{array}{l}\text { Bicycle commute } \\
\text { mode share }\end{array}$ & BL & $\begin{array}{l}\text { Population density } \\
\text { (+), } \\
\text { Transport demand } \\
\text { intensity (-) } \\
\text { (employees per } \\
\text { road length) }\end{array}$ & $\begin{array}{l}\% \text { of road and } \\
\text { bicycle } \\
\text { network that is } \\
\text { signed bicycle } \\
\text { routes, } \\
\% \text { of bicycle } \\
\text { network that } \\
\text { is off-road (+), } \\
\% \text { of bicycle } \\
\text { network that is } \\
\text { adjacent to the } \\
\text { road, } \\
\% \text { of road } \\
\text { network that } \\
\text { has a bicycle } \\
\text { or bus lane } \\
\text { off-road, } \\
\text { Probability of } \\
\text { acceptability of } \\
\text { cycling }\end{array}$ & $\begin{array}{l}\% \text { of ward that is male (+), } \\
\% \text { of ward that is non-white (-), } \\
\% \text { of ward with higher level qualifications, } \\
\% \text { of ward in age groups, } \\
\text { Cars per employee (-), } \\
\text { Deprivation income score (-), } \\
\% \text { with distance to work }<2 \mathrm{~km} \text {, } \\
\% \text { with distance to work } 2 \text { to } 5 \mathrm{~km}(-) \text {, } \\
\% \text { with distance to work } 5 \text { to } 20 \mathrm{~km}(-) \text {, } \\
\% \text { with distance to work }>20 \mathrm{~km}, \\
\text { Total annual hours of sunshine, } \\
\text { Annual rainfall (-), } \\
\text { Mean temperature (+), } \\
3 \% \text { (-), } \\
\text { Wind speed, } \\
\% \text { of principal road length deemed to } \\
\text { have failed (-), } \\
\% \text { of non-principal road length deemed } \\
\text { to have failed (-) }\end{array}$ \\
\hline
\end{tabular}


Table A-1: Studies of bicycling and the built environment

\begin{tabular}{|c|c|c|c|c|c|c|}
\hline Authors & Sample & $\begin{array}{c}\text { Travel Behavior } \\
\text { Dimension }\end{array}$ & Methods & $\begin{array}{l}\text { Built Form } \\
\text { Variables }\end{array}$ & $\begin{array}{c}\text { Bicycle } \\
\text { Infrastructure } \\
\text { Variables }\end{array}$ & Other Variables \\
\hline
\end{tabular}




\begin{tabular}{|c|c|c|c|c|c|c|}
\hline Authors & Sample & $\begin{array}{c}\text { Travel Behavior } \\
\text { Dimension }\end{array}$ & Methods & $\begin{array}{l}\text { Built Form } \\
\text { Variables }\end{array}$ & $\begin{array}{c}\text { Bicycle } \\
\text { Infrastructure } \\
\text { Variables }\end{array}$ & Other Variables \\
\hline $\begin{array}{l}\text { Zahran et } \\
\text { al. (2008) }\end{array}$ & $\begin{array}{l}\text { United States: } \\
\text { counts of } \\
\text { bicycle } \\
\text { commuters in } \\
2871 \text { counties }\end{array}$ & $\begin{array}{l}\text { Count of bicycle } \\
\text { commuters }\end{array}$ & ZINB & $\begin{array}{l}\text { Population density } \\
\qquad(+) \text {, } \\
\text { Hazardous air } \\
\text { pollution } \\
\text { emissions per } \\
\text { capita (-) }\end{array}$ & None & $\begin{array}{l}\text { No. of workers (+), } \\
\text { Avg. commute travel time (-), } \\
\text { Natural amenities scale (+), } \\
\text { Proximity to national parks and forests } \\
\quad(+), \\
\% \text { Hispanic population (+), } \\
\% \text { college educated population (+), } \\
\text { Median home value (+), } \\
\% \text { green party voters (+), } \\
\text { No. environmental non-profits (-), } \\
\text { No. bicycle advocacy organizations and } \\
\text { clubs (+) }\end{array}$ \\
\hline \multicolumn{7}{|c|}{ Disaggregate choice and use studies } \\
\hline $\begin{array}{l}\text { Akar and } \\
\text { Clifton } \\
(2009)\end{array}$ & $\begin{array}{l}\text { Washington, } \\
\text { D.C. area: } \\
997 \text { faculty, } \\
\text { students, and } \\
\text { staff traveling } \\
\text { to a large } \\
\text { university } \\
\text { campus }\end{array}$ & $\begin{array}{l}\text { Mode choice to } \\
\text { campus }\end{array}$ & $\begin{array}{l}\text { MNL, } \\
\text { PCA }\end{array}$ & None & $\begin{array}{l}\text { Attitudinal factor } \\
\text { for bike } \\
\text { parking on } \\
\text { campus }\end{array}$ & $\begin{array}{l}\text { Travel time (-), } \\
\text { Male gender (+), } \\
\text { Graduate student (+), } \\
\text { Attitudinal factor for weather affecting } \\
\text { travel/exercise/departure flexibility } \\
\text { (+), } \\
\text { Attitudinal factor for walking and } \\
\text { biking } \\
\text { safely after dark (+), } \\
\text { Attitudinal factor for high car parking cost } \\
\text { and limited travel options }\end{array}$ \\
\hline
\end{tabular}


Table A-1: Studies of bicycling and the built environment

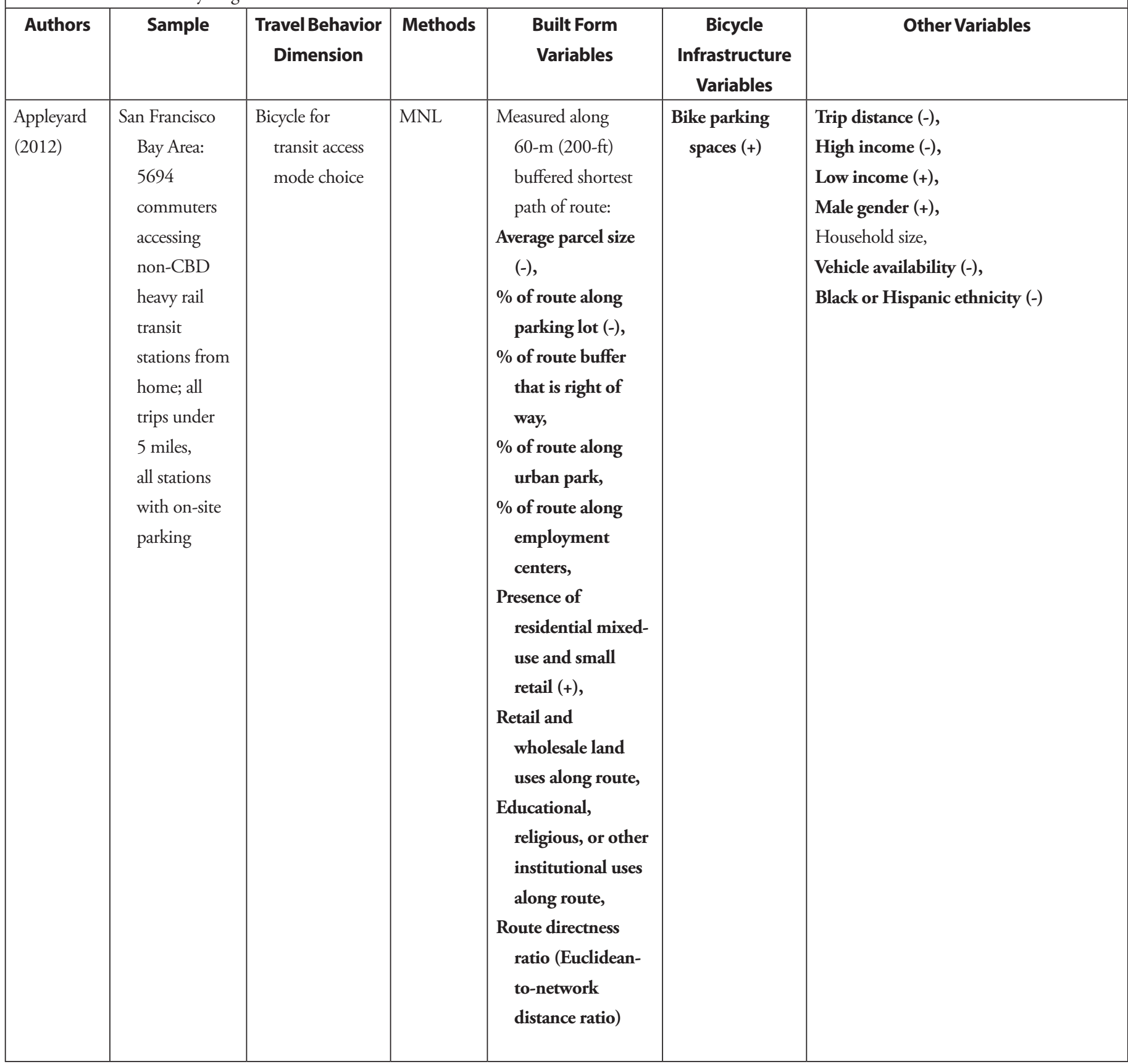




\begin{tabular}{|c|c|c|c|c|c|c|}
\hline Authors & Sample & $\begin{array}{c}\text { Travel Behavior } \\
\text { Dimension }\end{array}$ & Methods & $\begin{array}{l}\text { Built Form } \\
\text { Variables }\end{array}$ & $\begin{array}{c}\text { Bicycle } \\
\text { Infrastructure } \\
\text { Variables }\end{array}$ & Other Variables \\
\hline $\begin{array}{l}\text { Beenackers } \\
\text { et al. (2012) }\end{array}$ & $\begin{array}{l}\text { Perth, Australia: } \\
1427 \\
\text { individuals } \\
\text { that moved to } \\
\text { new housing } \\
\text { developments } \\
\text { and then } \\
\text { began cycling }\end{array}$ & $\begin{array}{l}\text { Bicycling for } \\
\text { transport and } \\
\text { recreation at } \\
\text { least once per } \\
\text { week }\end{array}$ & BL & $\begin{array}{l}\text { Objective measures } \\
\text { (1600-m buffer } \\
\text { around residence): } \\
\text { Land use mix, } \\
\text { Connectivity (+), } \\
\text { (recreational } \\
\text { cycling only), } \\
\text { Residential density } \\
\text { (+) } \\
\text { (transportation } \\
\text { cycling only), } \\
\text { Perceived measures: } \\
\text { Access to mixed } \\
\text { services, } \\
\text { Traffic hazards, } \\
\text { Major barriers, } \\
\text { Parking difficulty, } \\
\text { Access to parks (+) } \\
\text { (transportation } \\
\text { cycling only), } \\
\text { Alternative route } \\
\text { availability } \\
\text { No. transport } \\
\text { destinations, } \\
\text { No. recreation } \\
\text { destinations (+) } \\
\text { (transportation } \\
\text { cycling only), } \\
\text { Crime, } \\
\text { Neighborhood } \\
\text { available, } \\
\text { (16sings }\end{array}$ & $\begin{array}{l}\text { Perceived access } \\
\text { to cycling } \\
\text { paths }\end{array}$ & $\begin{array}{l}\text { Attitude, } \\
\text { Self-efficacy (+) (i.e. cycle in the rain no } \\
\text { matter what) (transportation cycling } \\
\text { only), } \\
\text { Social influence (+), } \\
\text { Intention (+) (recreational cycling only) }\end{array}$ \\
\hline
\end{tabular}


Table A-1: Studies of bicycling and the built environment

\begin{tabular}{|c|c|c|c|c|c|c|}
\hline Authors & Sample & $\begin{array}{c}\text { Travel Behavior } \\
\text { Dimension }\end{array}$ & Methods & $\begin{array}{l}\text { Built Form } \\
\text { Variables }\end{array}$ & $\begin{array}{c}\text { Bicycle } \\
\text { Infrastructure } \\
\text { Variables } \\
\end{array}$ & Other Variables \\
\hline $\begin{array}{l}\text { Cervero et } \\
\text { al. (2009) }\end{array}$ & $\begin{array}{l}\text { Bogota, } \\
\text { Colombia: } \\
830 \text { adults }\end{array}$ & $\begin{array}{l}\text { Utilitarian } \\
\text { bicycling for } \\
\text { >30mins per } \\
\text { weekday }\end{array}$ & HLM & $\begin{array}{l}\text { 500-m (0.3-mi) } \\
\text { and 1000-m (0.6- } \\
\text { mi) buffer areas } \\
\text { around home } \\
\text { neighborhood: } \\
\text { Residential density, } \\
\text { Land-use entropy } \\
\text { index, } \\
\text { Street density (+) } \\
\text { (road km/area), } \\
\text { Avg. lot size, } \\
\text { Connectivity index } \\
\text { (nodes-to-links } \\
\text { ratio), } \\
\text { Route directness, } \\
\text { Park density, } \\
\text { Presence of bus } \\
\text { rapid transit } \\
\text { station, } \\
\text { Number of stations, } \\
\text { Number of schools/ } \\
\text { hospitals/ } \\
\text { libraries/shopping } \\
\text { centers }\end{array}$ & Bike lane density & $\begin{array}{l}\text { Avg. automobile speed on main streets, } \\
\text { No. pedestrian bridges, } \\
\text { Traffic fatalities per year (-), } \\
\mathbf{3 \%}(-) \text {, } \\
\text { Male gender (+), } \\
\text { 18-35 age group, } \\
>\mathbf{3 5} \text { age group (-), } \\
\text { high school, } \\
\text { Education level > high school (-), } \\
\text { At least one vehicle in household (-) }\end{array}$ \\
\hline
\end{tabular}




\begin{tabular}{|c|c|c|c|c|c|c|}
\hline Authors & Sample & $\begin{array}{c}\text { Travel Behavior } \\
\text { Dimension }\end{array}$ & Methods & $\begin{array}{l}\text { Built Form } \\
\text { Variables }\end{array}$ & $\begin{array}{c}\text { Bicycle } \\
\text { Infrastructure } \\
\text { Variables }\end{array}$ & Other Variables \\
\hline $\begin{array}{l}\text { Ferrell and } \\
\text { Mathur } \\
(2012)\end{array}$ & $\begin{array}{l}\text { San Francisco } \\
\text { Bay Area: } \\
3630 \\
\text { commute } \\
\text { trips with } \\
\text { origins in } \\
\text { Berkeley, } \\
\text { Concord, } \\
\text { Oakland, San } \\
\text { Francisco, } \\
\text { Santa Clara, } \\
\text { Sunnyvale, or } \\
\text { Walnut Creek }\end{array}$ & $\begin{array}{l}\text { Mode choice for } \\
\text { work trips }\end{array}$ & MNL & $\begin{array}{l}\text { Household TAZ } \\
\text { characteristics } \\
\text { Transit accessibility } \\
\text { score (+), } \\
\text { Population density, } \\
\text { Jobs-housing } \\
\text { balance, } \\
\text { Intersection }\end{array}$ & None & $\begin{array}{l}\text { Trip distance (-), } \\
\text { Trip during peak period (-), } \\
\text { Race = white (+), } \\
\text { Age category, } \\
\text { Male gender (+), } \\
\text { Household income, } \\
\text { Home owner (-), } \\
\text { Home in San Francisco, } \\
\text { No. household bicycles (+), } \\
\text { Household vehicles per driver (-), } \\
\text { Household TAZ median income, } \\
\text { Household TAZ percent white, } \\
\text { Destination TAZ median income, } \\
\text { Part I violent crimes within } \mathbf{1 / 8} \text { mi of } \\
\quad \text { home (-) }\end{array}$ \\
\hline $\begin{array}{l}\text { Ferrell and } \\
\text { Mathur } \\
\text { (2012) }\end{array}$ & $\begin{array}{l}\text { San Francisco } \\
\text { Bay Area: } \\
1073 \text { non- } \\
\text { work trips } \\
\text { with origins } \\
\text { in Berkeley, } \\
\text { Concord, } \\
\text { Oakland, San } \\
\text { Francisco, } \\
\text { Santa Clara, } \\
\text { Sunnyvale, or } \\
\text { Walnut Creek }\end{array}$ & $\begin{array}{l}\text { Mode choice for } \\
\text { non-work trips }\end{array}$ & MNL & $\begin{array}{l}\text { Household TAZ } \\
\text { characteristics: } \\
\text { Transit accessibility } \\
\text { score, } \\
\text { Population density, } \\
\text { Jobs-housing } \\
\text { balance, } \\
\text { Intersection density }\end{array}$ & None & $\begin{array}{l}\text { Trip distance, } \\
\text { Trip during peak period, } \\
\text { Race = white, } \\
\text { Age category, } \\
\text { Male gender, } \\
\text { Household income, } \\
\text { Home owner (-), } \\
\text { Home in San Francisco, } \\
\text { No. household bicycles (+), } \\
\text { Household vehicles per driver (-), } \\
\text { Household TAZ median income, } \\
\text { Household TAZ percent white, } \\
\text { Destination TAZ median income, } \\
\text { Part I violent crimes within 1/8 mi of } \\
\text { home }\end{array}$ \\
\hline $\begin{array}{l}\text { Frank et al. } \\
(2008)\end{array}$ & $\begin{array}{l}\text { Puget Sound } \\
\text { region: } 8707 \\
\text { home-based } \\
\text { work tours } \\
\text { and 10,475 } \\
\text { home-based } \\
\text { other tours }\end{array}$ & $\begin{array}{l}\text { Tour mode } \\
\text { choice }\end{array}$ & MNL & $\begin{array}{l}\text { 1000-m (0.6-mi) } \\
\text { street network } \\
\text { distance buffers } \\
\text { @ origin and } \\
\text { destination: } \\
\text { Residential density, } \\
\text { Mixed use measure, } \\
\text { Intersection }\end{array}$ & None & $\begin{array}{l}\text { Travel time (-), } \\
\text { Age } 25-50(+) \text { (home-based work tours } \\
\text { only), } \\
\text { Age }>50 \text { (-) (home-based other tours } \\
\text { only), } \\
\text { Male gender (+) (home-based work tours } \\
\text { only), } \\
\text { Social or recreation stop(s) made }(+) \\
\text { (home-based other tours only) }\end{array}$ \\
\hline
\end{tabular}


Table A-1: Studies of bicycling and the built environment

\begin{tabular}{|c|c|c|c|c|c|c|}
\hline Authors & Sample & $\begin{array}{c}\text { Travel Behavior } \\
\text { Dimension }\end{array}$ & Methods & $\begin{array}{l}\text { Built Form } \\
\text { Variables }\end{array}$ & $\begin{array}{c}\text { Bicycle } \\
\text { Infrastructure } \\
\text { Variables }\end{array}$ & Other Variables \\
\hline
\end{tabular}




\begin{tabular}{|c|c|c|c|c|c|c|}
\hline Authors & Sample & $\begin{array}{c}\text { Travel Behavior } \\
\text { Dimension }\end{array}$ & Methods & $\begin{array}{l}\text { Built Form } \\
\text { Variables }\end{array}$ & $\begin{array}{c}\text { Bicycle } \\
\text { Infrastructure } \\
\text { Variables }\end{array}$ & Other Variables \\
\hline $\begin{array}{l}\text { Handy, } \\
\text { Xing, and } \\
\text { Buehler } \\
(2010)\end{array}$ & $\begin{array}{l}\text { Davis, CA; } \\
\text { Chico, CA; } \\
\text { Turlock, CA; } \\
\text { Woodland, CA; } \\
\text { Boulder, CO; } \\
\text { Eugene, OR: } \\
571 \text { individuals }\end{array}$ & $\begin{array}{l}\text { Bicycle } \\
\text { ownership and } \\
\text { use for trans- } \\
\text { portation and } \\
\text { recreation }\end{array}$ & NL & $\begin{array}{l}\text { Perceptions of: } \\
\text { Safety to access } \\
\text { typical non-work } \\
\text { destinations, } \\
\text { Access to transit }\end{array}$ & $\begin{array}{l}\text { Perceived } \\
\text { measures: City } \\
\text { has network } \\
\text { of off-street } \\
\text { paths (+), } \\
\text { Bike network has } \\
\text { big gaps, } \\
\text { Major streets } \\
\text { have bike } \\
\text { lanes, } \\
\text { Streets without } \\
\text { bike lanes are } \\
\text { wide enough } \\
\text { for cycling, } \\
\text { Stores and desti } \\
\text { nations have } \\
\text { bike racks, } \\
\text { Streets and bike } \\
\text { paths are } \\
\text { well-lit, } \\
\text { Intersections have } \\
\text { push buttons } \\
\text { for cyclists and } \\
\text { pedestrians, } \\
\text { Safety concern } \\
\text { while biking, } \\
\text { Bike lanes free } \\
\text { of obstacles } \\
\text { (-) }\end{array}$ & $\begin{array}{l}\text { Age (-), } \\
\text { Male gender, } \\
\text { Education level (+), } \\
\text { Household size, } \\
\text { Household income, } \\
\text { Owns a vehicle, } \\
\text { Homeowner, } \\
\text { White ethnicity, } \\
\text { Perceptions of: } \\
\text { Biking comfort (+), } \\
\text { In good health (+), } \\
\text { Rode bikes as a child, } \\
\text { Like walking, } \\
\text { Like transit, } \\
\text { Like bicycling, } \\
\text { Like to drive, } \\
\text { Need a car (-), } \\
\text { Try to limit driving, } \\
\text { Environmental concern (+), } \\
\text { Pro-exercise, } \\
\text { Prefer to live in bike-friendly commu- } \\
\text { nity } \\
\text { Hilly topography, } \\
\text { Distances (-), } \\
\text { Good driver attitude, } \\
\text { Biking is normal, } \\
\text { Kids bike (-), } \\
\text { Cyclists are poor, } \\
\text { Cyclists spend money, } \\
\text { Cyclists not worried about safety (+) }\end{array}$ \\
\hline
\end{tabular}


Table A-1: Studies of bicycling and the built environment

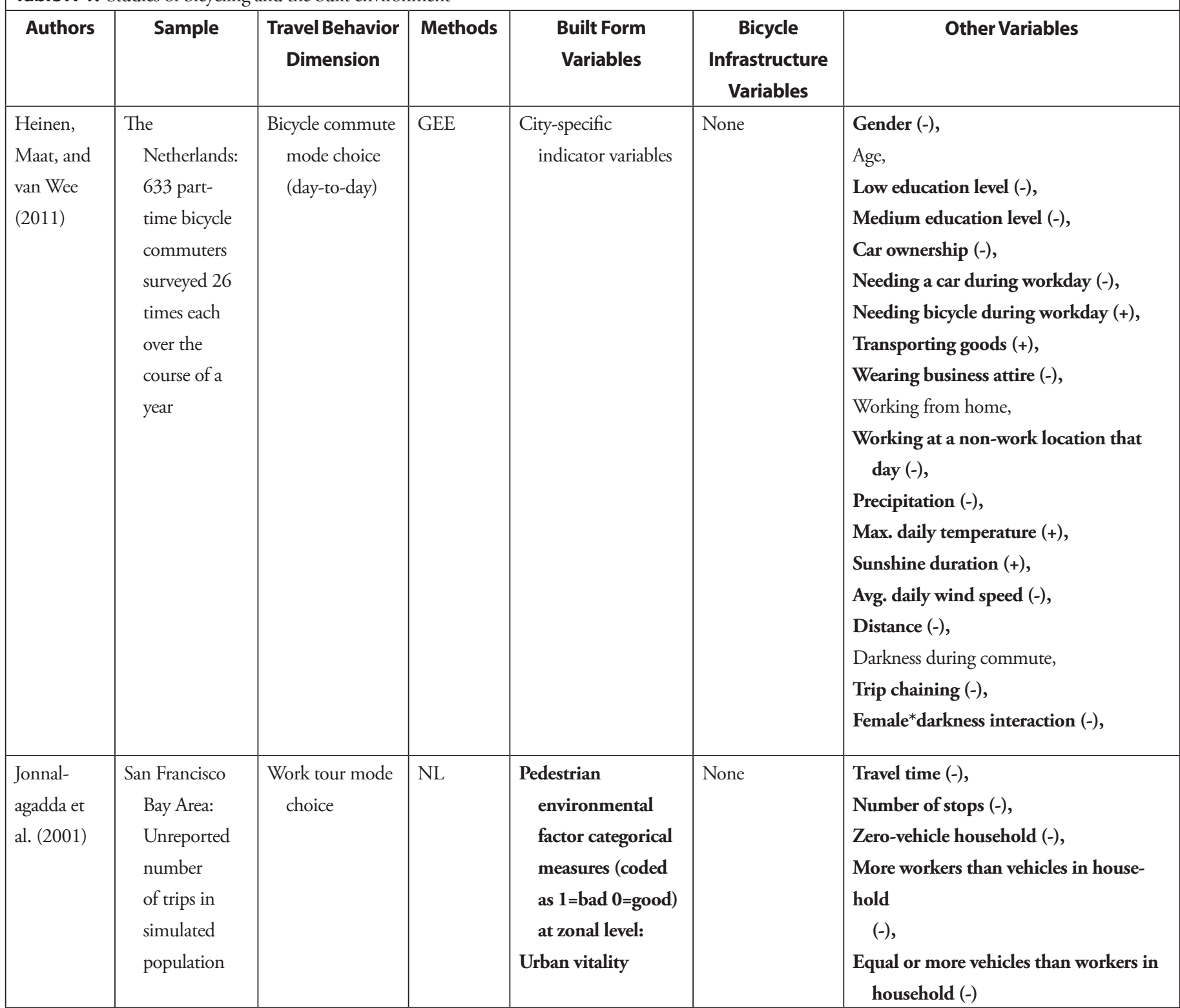




\begin{tabular}{|c|c|c|c|c|c|c|}
\hline Authors & Sample & $\begin{array}{c}\text { Travel Behavior } \\
\text { Dimension }\end{array}$ & Methods & $\begin{array}{l}\text { Built Form } \\
\text { Variables }\end{array}$ & $\begin{array}{c}\text { Bicycle } \\
\text { Infrastructure } \\
\text { Variables }\end{array}$ & Other Variables \\
\hline $\begin{array}{l}\text { Kim and } \\
\text { Ulfarsson } \\
(2008)\end{array}$ & $\begin{array}{l}\text { Puget Sound } \\
\text { region: } 2737 \\
\text { weekday short } \\
2250 \mathrm{~m}(1.4 \\
\text { mi) }\end{array}$ & Mode choice & $\begin{array}{l}\text { MNL, } \\
\text { PCA }\end{array}$ & $\begin{array}{l}\text { Urban index - a PCA } \\
\text { variable based on } \\
\text { U.S. population } \\
\text { density (home } \\
\text { Census block } \\
\text { group), } \\
\text { Median age of } \\
\text { buildings }\end{array}$ & None & $\begin{array}{l}\text { Age (-), } \\
\text { Male gender, } \\
\text { Ethnicity, } \\
\text { Education level, } \\
\text { Driver's license, } \\
\text { Bus pass (+), } \\
\text { Need vehicle at work, } \\
\text { Household income, } \\
\text { Length of residence, } \\
\text { Vehicle availability (-), } \\
\text { Household type = non-family (-), } \\
\text { Trip distance, } \\
\text { Accompanied by another on trip (-), } \\
\text { School trip purpose (+), } \\
\text { Social/recreational trip purpose (+) }\end{array}$ \\
\hline $\begin{array}{l}\text { Krizek and } \\
\text { Johnson } \\
(2006)\end{array}$ & $\begin{array}{l}\text { Minneapolis } \\
\text { and St. Paul, } \\
\text { MN: } 1653 \\
\text { individuals }\end{array}$ & $\begin{array}{l}\text { Bicycle mode } \\
\text { choice }\end{array}$ & BL & None & $\begin{array}{l}\text { Distance from } \\
\text { home to on- } \\
\text { street bicycle } \\
\text { lanes: } \\
\text { Distance <400m } \\
(+), \\
\text { Distance 400- } \\
799 \mathrm{~m}, \\
\text { Distance } 800- \\
1599 \mathrm{~m}, \\
1600 \mathrm{~m}\end{array}$ & $\begin{array}{l}\text { Male gender (+), } \\
\text { College education level (+), } \\
\text { Employed, } \\
\text { Age } 40-59 \text {, } \\
\text { Age } 60 \text { or more (-), } \\
\text { Household income (-) } \\
\text { Children in household (-), } \\
\text { Household bicycles (+), } \\
\text { Household vehicles (-) }\end{array}$ \\
\hline
\end{tabular}


Table A-1: Studies of bicycling and the built environment

\begin{tabular}{|c|c|c|c|c|c|c|}
\hline Authors & Sample & $\begin{array}{c}\text { Travel Behavior } \\
\text { Dimension }\end{array}$ & Methods & $\begin{array}{l}\text { Built Form } \\
\text { Variables }\end{array}$ & $\begin{array}{c}\text { Bicycle } \\
\text { Infrastructure } \\
\text { Variables }\end{array}$ & Other Variables \\
\hline
\end{tabular}




\begin{tabular}{|c|c|c|c|c|c|c|}
\hline Authors & Sample & $\begin{array}{c}\text { Travel Behavior } \\
\text { Dimension }\end{array}$ & Methods & $\begin{array}{l}\text { Built Form } \\
\text { Variables }\end{array}$ & $\begin{array}{c}\text { Bicycle } \\
\text { Infrastructure } \\
\text { Variables }\end{array}$ & Other Variables \\
\hline $\begin{array}{l}\text { Plaut } \\
(2005)\end{array}$ & $\begin{array}{l}\text { United States: } \\
3423 \\
\text { individuals } \\
\text { who work at } \\
\text { home, walk } \\
\text { to work, } \\
\text { or bike to } \\
\text { work. Results } \\
\text { presented } \\
\text { across house- } \\
\text { hold renter } \\
\text { or owner } \\
\text { categories }\end{array}$ & $\begin{array}{l}\text { Walk commute } \\
\text { mode choice, } \\
\text { bicycle commute } \\
\text { mode choice }\end{array}$ & $\mathrm{BL}$ & $\begin{array}{l}\text { Perceived measures: } \\
\text { Shopping services } \\
\text { nearby, } \\
\text { Green areas nearby, } \\
\text { Apartment } \\
\text { builings nearby, } \\
\text { Single family homes }\end{array}$ & None & $\begin{array}{l}\text { Commute distance, } \\
\text { Avg. commute time, } \\
\text { Male gender (+), } \\
\text { Age, } \\
\text { Marital status, } \\
\text { Household size, } \\
\text { College graduate (+) (renters only), } \\
\text { Postgraduate education beyond BA (+), } \\
\text { Non-white ethnicity (-), } \\
\text { Salary (-), } \\
\text { Household income, } \\
\text { Zero vehicles owned (+), } \\
\text { Two or more vehicles owned (-) } \\
\text { (homeowners only), } \\
\text { Whether there is presence of income from } \\
\text { dividends, } \\
\text { Household insurance premiums, } \\
\text { Value of home (-) (homeowners only), } \\
\text { Cost of rent (+) (renters only), } \\
\text { Area of floor space of home, } \\
\text { No. bedrooms in home, } \\
\text { No. bathrooms in home (-) (renters } \\
\text { only), } \\
\text { Whether housing has a garage or } \\
\text { parking space (-) (homeowners only), } \\
\text { Whether home has a cellar, } \\
\text { Age of home (+), } \\
\text { Subjective quality rating of home }\end{array}$ \\
\hline $\begin{array}{l}\text { Rajamani et } \\
\text { al. (2003) }\end{array}$ & $\begin{array}{l}\text { Portland, OR: } \\
2500 \\
\text { home-based } \\
\text { non-work } \\
\text { trips of } 369 \\
\text { households }\end{array}$ & Mode choice & MNL & $\begin{array}{l}\text { At origin Census } \\
\text { blocks: } \\
\text { \% households } \\
\text { within "walking } \\
\text { distance" of bus, } \\
\text { Population density, } \\
\text { Land-use mix diver }\end{array}$ & None & $\begin{array}{l}\text { Household income, } \\
\text { Vehicles per adult (-), } \\
\text { No. of children (-), } \\
\text { No. of adults, } \\
\text { Age (-), } \\
\text { Physically handicapped, } \\
\text { White ethnicity, } \\
\text { Travel time (-), } \\
\text { Travel cost (-), }\end{array}$ \\
\hline
\end{tabular}


Table A-1: Studies of bicycling and the built environment

\begin{tabular}{|c|c|c|c|c|c|c|}
\hline Authors & Sample & $\begin{array}{c}\text { Travel Behavior } \\
\text { Dimension }\end{array}$ & Methods & $\begin{array}{l}\text { Built Form } \\
\text { Variables }\end{array}$ & $\begin{array}{c}\text { Bicycle } \\
\text { Infrastructure } \\
\text { Variables }\end{array}$ & Other Variables \\
\hline
\end{tabular}




\begin{tabular}{|c|c|c|c|c|c|c|}
\hline Authors & Sample & $\begin{array}{c}\text { Travel Behavior } \\
\text { Dimension }\end{array}$ & Methods & $\begin{array}{l}\text { Built Form } \\
\text { Variables }\end{array}$ & $\begin{array}{c}\text { Bicycle } \\
\text { Infrastructure } \\
\text { Variables }\end{array}$ & Other Variables \\
\hline $\begin{array}{l}\text { Schneider } \\
(2011)\end{array}$ & $\begin{array}{l}\text { San Francisco } \\
\text { Bay Area: } 959 \\
\text { customers at } \\
20 \text { retail phar- } \\
\text { macy stores }\end{array}$ & $\begin{array}{l}\text { Tour mode } \\
\text { choice to shop- } \\
\text { ping districts }\end{array}$ & HLM & $\begin{array}{l}\text { Employment } \\
\text { density at destina- } \\
\text { tions ( } 800-\mathrm{m} / 0.5- \\
\text { mi buffer), } \\
\text { Population } \\
\text { density at destina- } \\
\text { tions (160-m/0.1- } \\
\text { mi buffer), } \\
\% \text { multilane road } \\
\text { tree canopy within } \\
800 \text { m/0.5 mi, } \\
\text { Parking spaces at } \\
\text { destination, } \\
\text { Distance to train } \\
\text { station, } \\
\text { Metered on-street } \\
\text { parking }\end{array}$ & $\begin{array}{l}\text { Within } 800 \mathrm{~m} \\
(0.5 \mathrm{mi}) \text { of } \\
\text { destinations: } \\
\text { Bike facilities } \\
\text { density (+), } \\
\text { Bike parking } \\
\text { spaces }\end{array}$ & $\begin{array}{l}\text { Tour distance (-), } \\
\text { Tour distance < } 3.2 \mathrm{~km} / 2 \mathrm{mi} \text {, } \\
\text { Number of tour stops, } \\
\text { No shopping bags, } \\
\text { Shopping alone, } \\
\text { Male gender (+), } \\
\text { Spanish speaker, } \\
\text { Student, } \\
\text { Group household, } \\
\text { Bus pass, } \\
\text { Physical disability, } \\
\text { Zero-car household, } \\
\text { Perceptions of: } \\
\text { Enjoy walking, } \\
\text { Crime risk, } \\
\text { Crash risk, }\end{array}$ \\
\hline
\end{tabular}




\begin{tabular}{|c|c|c|c|c|c|c|}
\hline Authors & Sample & $\begin{array}{c}\text { Travel Behavior } \\
\text { Dimension }\end{array}$ & Methods & $\begin{array}{l}\text { Built Form } \\
\text { Variables }\end{array}$ & $\begin{array}{c}\text { Bicycle } \\
\text { Infrastructure } \\
\text { Variables }\end{array}$ & Other Variables \\
\hline $\begin{array}{l}\text { Vernez- } \\
\text { Moudon et } \\
\text { al. }(2005)\end{array}$ & $\begin{array}{l}\text { King County, } \\
\text { WA: } 608 \\
\text { adults }\end{array}$ & $\begin{array}{l}\text { Bicycling at least } \\
\text { once per week } \\
\text { for trans- } \\
\text { portation or } \\
\text { recreation }\end{array}$ & $\mathrm{BL}$ & $\begin{array}{l}\text { Perceived measures } \\
\text { in neighbor- } \\
\text { hood: Presence of } \\
\text { grocery shops and } \\
\text { schools (+), } \\
\text { Presence of } \\
\text { auto-oriented } \\
\text { facilities (-), } \\
\text { Problems related to } \\
\text { automobiles (-) } \\
\text { Objective measures } \\
\text { (3-km/1.9-mi buf- } \\
\text { fer around home): } \\
\text { Number of parks, } \\
\text { Footprint area of } \\
\text { convenience stores } \\
\text { (including gas } \\
\text { stations) (-), Size } \\
\text { of nearest grocery } \\
\text { or restaurant, } \\
\text { No. office/fast food/ } \\
\text { hospital parcels } \\
\text { (+) }\end{array}$ & $\begin{array}{l}\text { Perceived } \\
\text { amenities for } \\
\text { jogging or } \\
\text { cycling (+), } \\
\text { Objective mea- } \\
\text { sures: } \\
\% \text { of streets lined } \\
\text { with bicyclel- } \\
\text { anes, } \\
\text { Distance to } \\
\text { nearest trail }\end{array}$ & $\begin{array}{l}\text { Male gender (+), } \\
\text { Age, } \\
\text { Transit user (+), } \\
\text { Exercise at home (+), } \\
\text { White ethnicity (+), } \\
\text { Less than sufficient physical activity } \\
\text { level } \\
\quad(-) \text {, } \\
\text { Bicycle ownership (+), } \\
<2 \text { vehicles per household adult (-), } \\
\text { Marital status, } \\
\text { No. facilitators for cycling (+), } \\
\text { Knowledge of physical activity benefits } \\
\text { of cycling (-), } \\
\text { Weekly work hours (-) }\end{array}$ \\
\hline
\end{tabular}




\begin{tabular}{|c|c|c|c|c|c|c|}
\hline Authors & Sample & $\begin{array}{c}\text { Travel Behavior } \\
\text { Dimension }\end{array}$ & Methods & $\begin{array}{l}\text { Built Form } \\
\text { Variables }\end{array}$ & $\begin{array}{c}\text { Bicycle } \\
\text { Infrastructure } \\
\text { Variables }\end{array}$ & Other Variables \\
\hline $\begin{array}{l}\text { Winters et } \\
\text { al. (2010) }\end{array}$ & $\begin{array}{l}\text { Vancouver, } \\
\text { Canada: } 3280 \\
\text { bicycle and car } \\
\text { trips }\end{array}$ & Mode choice & HLM & 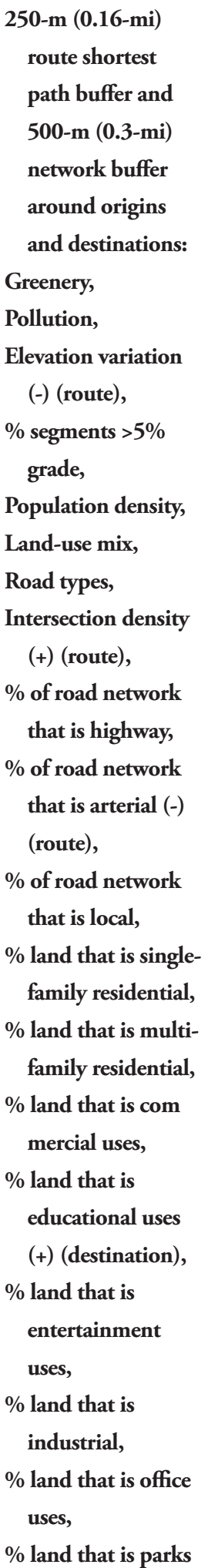 & $\begin{array}{l}\% \text { of road } \\
\text { network that } \\
\text { is bike routes, } \\
\% \text { that is } \\
\text { off-street } \\
\text { paths, } \\
\text { Presence of } \\
\text { traffic calm- } \\
\text { ing features, } \\
\text { Presence of bike } \\
\text { route signage, } \\
\text { Presence of } \\
\text { cyclist-acti- } \\
\text { vated traffic } \\
\text { signals }\end{array}$ & $\begin{array}{l}\text { Male gender }(+) \text {, } \\
\text { Age }<65(+) \text {, } \\
\text { Education }>\text { high school }(+), \\
\text { Household income }<\$ 90,000(+) \text {, } \\
\text { Trip distance }(-)\end{array}$ \\
\hline
\end{tabular}


Table A-1: Studies of bicycling and the built environment

\begin{tabular}{|c|c|c|c|c|c|c|}
\hline Authors & Sample & $\begin{array}{c}\text { Travel Behavior } \\
\text { Dimension }\end{array}$ & Methods & $\begin{array}{l}\text { Built Form } \\
\text { Variables }\end{array}$ & $\begin{array}{c}\text { Bicycle } \\
\text { Infrastructure } \\
\text { Variables } \\
\end{array}$ & Other Variables \\
\hline
\end{tabular}




\begin{tabular}{|c|c|c|c|c|c|c|}
\hline Authors & Sample & $\begin{array}{c}\text { Travel Behavior } \\
\text { Dimension }\end{array}$ & Methods & $\begin{array}{l}\text { Built Form } \\
\text { Variables }\end{array}$ & $\begin{array}{c}\text { Bicycle } \\
\text { Infrastructure } \\
\text { Variables }\end{array}$ & Other Variables \\
\hline \multicolumn{7}{|c|}{ Disaggregate route choice studies } \\
\hline $\begin{array}{l}\text { Broach et } \\
\text { al. (2012) }\end{array}$ & $\begin{array}{l}\text { Portland, OR: } \\
1449 \text { GPS- } \\
\text { recorded } \\
\text { utilitarian } \\
\text { cycling trips } \\
\text { by } 164 \text { bicy- } \\
\text { clists (revealed } \\
\text { preference) }\end{array}$ & Route choice & $\begin{array}{c}\text { Path-size } \\
\text { Logit }\end{array}$ & None & $\begin{array}{l}\text { Proportion of } \\
\text { route along } \\
\text { bicycle boule- } \\
\text { vards (+), } \\
\text { Proportion of } \\
\text { route along } \\
\text { bike path (+), } \\
\text { Bridge with bike } \\
\text { facilities (+) }\end{array}$ & $\begin{array}{l}\text { Distance (-), } \\
\text { Turns (-), } \\
\text { Proportion of route at } 2-4 \% \text { upslope (-), } \\
\text { Proportion of route at } 4-6 \% \text { upslope (-), } \\
\text { Proportion of route at } \geq 6 \% \text { upslope (-), } \\
\text { Stop signs (-), } \\
\text { No. of non-right turn movements at } \\
\text { signalized intersections (-), } \\
\text { Many interacted variables with traffic } \\
\text { volumes (-) }\end{array}$ \\
\hline $\begin{array}{l}\text { Menghini } \\
\text { et al. (2010) }\end{array}$ & $\begin{array}{l}\text { Zurich, } \\
\text { Switzer- } \\
\text { land: } 3387 \\
\text { unlinked } \\
\text { GPS-recorded } \\
\text { cycling trips } \\
\text { (revealed } \\
\text { preference) }\end{array}$ & Route choice & MNL & None & $\begin{array}{l}\text { Proportion of } \\
\text { route that } \\
\text { is a marked } \\
\text { bicycle route } \\
(+)\end{array}$ & $\begin{array}{l}\text { Distance (-), } \\
\text { No. of traffic lights (+), } \\
\text { Max. slope on route (-), } \\
\text { Avg. speed (+) }\end{array}$ \\
\hline
\end{tabular}




\begin{tabular}{|c|c|c|c|c|c|c|}
\hline Authors & Sample & $\begin{array}{c}\text { Travel Behavior } \\
\text { Dimension }\end{array}$ & Methods & $\begin{array}{l}\text { Built Form } \\
\text { Variables }\end{array}$ & $\begin{array}{c}\text { Bicycle } \\
\text { Infrastructure } \\
\text { Variables }\end{array}$ & Other Variables \\
\hline $\begin{array}{l}\text { Sener et al. } \\
(2009)\end{array}$ & $\begin{array}{l}\text { Texas: } 6484 \\
\text { choice occa- } \\
\text { sions from } \\
\text {,621 bicyclists } \\
\text { recruited } \\
\text { from a web } \\
\text { survey (stated } \\
\text { preference) }\end{array}$ & Route choice & $\begin{array}{l}\text { Panel } \\
\text { mixed } \\
\text { MNL }\end{array}$ & $\begin{array}{l}\text { Parallel parking } \\
\text { permitted along } \\
\text { route (-), } \\
\text { Angle parking } \\
\text { permitted (-), } \\
\text { Parking turnover } \\
\text { rate (-), } \\
\text { Length of parking } \\
\text { area (-), } \\
\text { Parking occupancy } \\
\text { rate = moderate } \\
\text { (-), } \\
\text { Parking occupancy } \\
\text { rate = high (-) }\end{array}$ & $\begin{array}{l}\text { 1.1-m (3.75-ft) } \\
\text { wide bike } \\
\text { lane, } \\
\text { 1.9-m (6.25-ft) } \\
\text { wide bike } \\
\text { lane, } \\
\text { No bike lane } \\
\text { with 3.2-m } \\
\text { (10.5-ft) wide } \\
\text { outside lane } \\
\text { (+), } \\
\text { No bike lane } \\
\text { with } \geq 4.3 \text {-m } \\
\text { (14-ft) wide } \\
\text { outside lane } \\
\text { (+), } \\
\text { Continuous } \\
\text { bikeway route } \\
\text { (+) }\end{array}$ & $\begin{array}{l}\text { Travel time (-), } \\
\text { Moderate hills cf. flat (+), } \\
\text { Steep hills cf. flat (-), } \\
\text { Amount of stop signs, red lights, and } \\
\quad \text { cross streets along route (-), } \\
\text { Traffic volumes (commute trips) (-), } \\
\text { Traffic volumes (non-commute trips) } \\
\text { (+), } \\
\text { Speed limit (-) }\end{array}$ \\
\hline $\begin{array}{l}\text { Stinson and } \\
\text { Bhat (2003) }\end{array}$ & $\begin{array}{l}\text { United States: } \\
3145 \text { bicycle } \\
\text { commuters } \\
\text { recruited } \\
\text { from a web } \\
\text { stated prefer- } \\
\text { ence survey } \\
\text { (note: } 7 \% \text { of } \\
\text { sample out- } \\
\text { side U.S.) }\end{array}$ & $\begin{array}{l}\text { Commute route } \\
\text { choice }\end{array}$ & $\mathrm{BL}$ & $\begin{array}{l}\text { Connectivity } \\
\text { measured as urban } \\
\text { morphology } \\
\text { variables: }\end{array}$ & $\begin{array}{l}\text { Continuous } \\
\text { facility (+), } \\
\text { Separated path } \\
(+), \\
\text { Bike lane (+), } \\
\text { Bike lane with } \\
\text { on-street } \\
\text { parking (-), } \\
\text { Wide right-hand } \\
\text { lane (+), } \\
\text { Bridge with bike } \\
\text { facility (+), }\end{array}$ & $\begin{array}{l}\text { Travel Time (-), } \\
\text { Major arterial links (-), } \\
\text { Minor arterial links (-), } \\
\text { Smooth pavement (+), } \\
\text { Coarse/sandy pavement (-), } \\
\text { Stop signs per mile (-), } \\
\text { No. of red lights (-), } \\
\text { No. of cross-streets (-), } \\
\text { Hilliness in urban areas (-), } \\
\text { Mountainous areas (-) }\end{array}$ \\
\hline
\end{tabular}

Note: bold indicates significant result, "(+)" indicates positive association, "(-)" indicates negative association.

$\mathrm{BL}=$ binary logit model, $\mathrm{GEE}=$ generalized estimation equations, $\mathrm{HLM}=$ multilevel $/$ mixed logit model, $\mathrm{MNL}=$ multinomial logit model, $\mathrm{NL}=$ nested logit model, OLS = ordinary least squares model, ZINB = zero-inflated negative binomial model, FA = factor analysis used for built form variables, $\mathrm{PCA}=$ principal components analysis used for built form variables 